\title{
Piec jako nośnik idei?
}

A stove as an idea medium?

Wprawdzie Jan Sas-Zubrzycki w 1915 roku, ze względu na ostrość klimatu, usiłował udowodnić polski rodowód kafli i pieców kaflowych, jednak nie był to nasz wynalazek (Sas Zubrzycki 1915, s. 3). Zostały one przejęte na fali przemian cywilizacyjnych jakie następowały na ziemiach polskich poczynając od przełomu XII i XIII wieku. Również zmiany osadnicze, powstanie i rozwój miast, rozwój rzemiosł i handlu, zmiany w budownictwie rzutowały na rozbudowę domu mieszkalnego oraz zagospodarowanie jego wnętrza (Rutkowska-Płachcińska 1978a, s. 11-39; 1978b, s. 150-179; 1978c, s. 312-357). Miały istotny wpływ na warunki życia codziennego powodując również zmiany w sposobach ogrzewania i rozwój urządzeń grzewczych. Włączenie ziem polskich w zasięg zachodniego kręgu kulturowego spowodowało, że tradycyjne, znane i stosowane do wczesnego średniowiecza paleniska otwarte i znacznie rzadsze piece kopułkowe zastępowano od XIII wieku, przynajmniej w obiektach o charakterze rezydencjonalnym, kominkami i ogrzewaniem podpodłogowym z piecami hypocaustycznymi. Natomiast powstawanie miast $\mathrm{i}$ zmiany zachodzące $\mathrm{w}$ wyniku napływu ludności w ramach kolonizacji na prawie niemieckim spowodowały, że od 2. połowy XIII wieku stawiano także piece kaflowe, początkowo budowane $\mathrm{z}$ kafli garnkowych i miskowych, a od XV wieku także płytowych (Dąbrowska 2008). Ich adaptacja w polskich warunkach przebiegała w różny sposób. Budowa kominków i pieców hypocaustycznych, jako części substancji murowanej budynków, należała do obowiązków budowniczych. Wykonanie przewodów kominowych, a więc i ustalenie lokalizacji pieców w budynkach także spoczywało w ich gestii. Natomiast następny etap związany już z wyposażaniem wnętrza, czyli wybór typu, wielkości i wystroju przyszłego grzejnika jest w zasadzie trudny do uchwycenia w źródłach, ale też nie za bardzo poświęcano temu problemowi uwagę. Znamy dopiero zdunów/ /garncarzy, którzy trudnili się wyrobem kafli i także stawianiem pieców. 
Pośród bogatego asortymentu wyrobów garncarskich kafle stanowiły szczególną kategorię. Ich pojedyncze egzemplarze nie spełniały żadnej funkcji i dopiero użyte we właściwej ilości i odpowiednio zestawione stawały się urządzeniem grzewczym o określonych parametrach i konstrukcji. Jednocześnie dość szybko odkryto, że mogły spełniać drugą, nie mniej ważną funkcję - stałego elementu wzbogacającego wystrój wnętrza. Już stawiając piec z kafli garnkowych i miskowych, umieszczając obok siebie kafle o różnych kształtach otworów i wielkościach, uzyskiwano ozdobne ściany. Jednak dopiero zastosowanie kafli płytowych stwarzało możliwość rozbudowy bryły i przekazywania bogatych i zróżnicowanych tematycznie programów ikonograficznych. Dodatkowo efekty wizualne wzmacniano reliefowym ornamentem i odmienną kolorystyką stosowanych polew. Tak więc piec z jednej strony był urządzeniem grzewczym, który aby zapewnić w miarę komfortowe warunki cieplne musiał spełniać wszelkie wymagania konstrukcyjne związane z działaniem ognia, z drugiej zaś strony był stałym, ozdobnym elementem wyposażenia wnętrza i, jak wykazały badania, mającym powiązania $\mathrm{z}$ aktualnym stylem i modą panującą $\mathrm{w}$ sztukach zdobniczych. Niewątpliwie odzwierciedlał także upodobania i gusty przede wszystkim właściciela wyposażanego budynku. O tym, że były one różne świadczą liczne znaleziska bogato zdobionych kafli.

Mimo, że piece przejęto z kultury zachodniej i niewątpliwie wzorowano się na urządzeniach znanych z terenu sąsiednich krajów - Austrii, Węgier, Czech i Niemiec, nie były one ich bezpośrednimi replikami. Powstaje więc pytanie kto w polskich warunkach był projektantem owych pieców i opracowywał ich wystrój. Trudno sobie wyobrazić, aby garncarz/zdun, producent kafli, był twórcą „artystycznej wizji pieca” i zgrania jej - jakby nie było - z konstrukcyjnymi wymogami urządzenia grzewczego. Wydaje się, że przynajmniej w okresie adaptacji przekraczało to możliwości zawodowe tej grupy rzemieślników.

Odtwarzając proces powstawania pieca wypada przyjąć, że w pierwszym etapie prac niewątpliwie konieczne było ustalenie wielkości grzejnika i kompozycji zdobiących go ornamentów, które - o czym trzeba pamiętać - winny tworzyć spójną stylistycznie całość. Jak można przypuszczać wiązało się to z wyborem wzorów graficznych dla całej bryły i poszczególnych jej elementów. Następnie należało wykonać pozytywowe modele zwane patrycami. $Z$ nich dopiero przygotowywano negatywy matryc, w których garncarz odciskał ornamentowane płytki licowe. Dzięki temu istniała możliwość wielokrotnego ich powielania. Również ostatni etap prac związany z wytwarzaniem kafli, polegający na ich formowaniu, suszeniu, wypalaniu i pokrywaniu glazurą należał do garncarza-zduna.

Wykonawców związanych z opracowywaniem brył pieców najprawdopodobniej należy upatrywać wśród osób związanych z projektowaniem budynków. Początkowo, w okresie gotyku, kiedy nie znano jeszcze osoby architekta - głównego projektanta, byli to zapewne członkowie zespołów wykonawczych tworzących 
tak zwane strzechy budowlane. Pracowali w nich również rzeźbiarze, a podział kompetencji wytwórców dotyczył nie tylko wykonania technicznego, ale także projektowania (Kębłowski 1976, s. 10-11). Budowniczowie współpracując z cechami mieli także kontakty ze snycerzami i zapewne oni, na podstawie przygotowanych projektów, wykonywali zarówno patryce, jak i matryce do kafli. Jako wzorce wykorzystywali niewątpliwie elementy sztuki zdobniczej, detale architektoniczne, grafiki książkowe, druki ulotne, drzeworyty i miedzioryty docierające od średniowiecza na tereny ziem polskich (Piątkiewicz-Dereniowa 1960a, s. 312-313; Janiak 2003, s. 32-33).

Wyobrażenie o bogactwie ornamentyki kafli gotyckich z terenu ziem polskich pozyskaliśmy właściwie dopiero pod koniec XX wieku dzięki pracom wykopaliskowym przeprowadzonym między innymi w obrębie wieży mieszkalnej w Jarocinie (Grygiel 1989; 2001) oraz dworu obronnego w Jankowie Dolnym koło Gniezna (Strzyżewski 1993a, s. 37-39), a także na terenie miasta oraz w strefie brzegowej Jeziora Świętego w Gnieźnie (Sawicki 1993, s. 40-43; Janiak 2003, s. 8-13, 20-24; 2007, s. 17-35). Zwłaszcza w tym ostatnim przypadku pozyskano cenne materiały źródłowe w postaci kilkunastu tysięcy fragmentów kafli i całych egzemplarzy, pochodzących ze zniszczonych pieców, które znajdowały się w budynkach należących do arcybiskupstwa. Równie interesujące zespoły znaleziono podczas badań rezydencji biskupów włocławskich w Raciążku (Nadolska 1988, s. 85-100) oraz z zamków w Bolesławcu (Żemigała 1987, s. 13-24), Wleniu (Dymek 1995, s. 207-222), Chudowie (Tarasiński 2007, s. 45-49), Ujeździe (Kajzer 2007, s. 21-31). Wszystkie kafle były zdobione ornamentem reliefowym, a wśród motywów można wydzielić klika różnych, powtarzających się grup przedstawień - o tematyce heraldycznej, religijnej (uwzględniające sceny ze Starego i Nowego Testamentu oraz symbolikę religijną), sceny z życia dworu (które również mogły mieć wymowę symboliczną), sceny o charakterze ludycznym i ilustrujące znane wówczas, a nie zawsze może dla nas zrozumiałe opowieści, a także motywy architektoniczne, zwierzęce i stylizowane roślinne.

Przy tak dużym zróżnicowaniu tematyki przedstawień trudno mówić o programie ikonograficznym poszczególnych pieców. Sądzę, że podjęcie takich prób jest możliwe jedynie w sytuacji, kiedy dysponujemy w miarę pełnymi zespołami kafli, które dodatkowo można identyfikować z pojedynczymi piecami. Warunki te niewątpliwie spełniają kafle z Jankowa Dolnego, stratygraficznie rozdzielone na dwa zespoły piecowe. Pierwszy z nich datowany jest przez Czesława Strzyżewskiego na 1. połowę XV wieku, drugi na 2. połowę tego stulecia (Strzyżewski 1993, s. 38). W starszym zespole autor wyróżnił 19 kafli garnkowych, $5 \mathrm{z}$ ażurowymi płytkami frontowymi i około 170 zdobionych okazów płytowych. Wśród rozpoznanych motywów wyodrębnił ponad 30 herbów państwowych, ziemskich, rycerskich i dostojników kościelnych - Jagiellonów, hrabiów Cyllejskich, arcybiskupów gnieźnieńskich Wojciecha Jastrzębca i Jana Odrowąża ze Sprowy (ryc. 1-4) 
oraz 13 z przedstawieniami o tematyce religijnej (ryc. 5-7), a także ze scenami dworskimi (ryc. 8), scenami z polowań, z przedstawieniami zwierząt i fantastycznych stworów. W piecu z 2. połowy XV wieku badacz stwierdził również herby państwowe - Orła i Pogoń, rycerskie - między innymi Grzymała, Jastrzębiec, Leliwa, Poraj, dostojników kościelnych, a także kafle o tematyce religijnej i dworskiej oraz zdobione plecionką i motywami roślinnymi (Strzyżewski 1993, s. 37-38). Analogiczny zestaw tematyki zdobniczej wyróżnił Ryszard Grygiel na kaflach z pieca w Jarocinie; na 50 zrekonstruowanych egzemplarzach znalazły się przedstawienia heraldyczne - Orła w koronie, herby Wielkopolski, Kapituły Gnieźnieńskiej oraz liczne herby rycerskie. Ponadto były też kafle zdobione scenami dworskimi, religijnymi i postaciami świętych oraz z przedstawieniami zwierząt i zabaw dworskich. Piec datowany jest na koniec XV-początek XVI wieku (Grygiel 1989, s. 6-17; 1993, s. 35-36; 2001, s. 219-251).

Ustalenia poczynione na podstawie jednostkowych pieców potwierdzają badania zespołów o przypadkowym zestawie kafli, na przykład z Jeziora Świętego w Gnieźnie. Nie wiemy z ilu pieców pochodziły, które współwystępowały ze sobą w poszczególnych bryłach oraz jaki procent zestawów stanowią, jednak zawsze wyróżniano te same tematyczne grupy motywów. Analogiczną ornamentykę rozpoznano również na kaflach gotyckich z innych obiektów, jak chociażby z zamku biskupów włocławskich w Raciążku (Nadolska 1988, s. 89-93), na kaflach z Ujazdu wyróżniała się grupa egzemplarzy z herbami (Kajzer 2007, s. 21-30). Spośród kafli z początku XVI wieku, znalezionych na zamku w Bolesławcu, Maria Żemigała odtworzyła jeden z pieców nazywając go „herbowym” (Żemigała 1987, s. 30-34). Bogato zdobione kafle gotyckie odkryto także na zamku w Inowłodzu (Motylewska 2008, s. 30-33); w tych przypadkach również nie wiemy z ilu pieców pochodzą pozyskane materiały źródłowe.

Przywołane przykłady upoważniają do przyjęcia założenia, że w poszczególnych piecach gotyckich obowiązywał jednolity wzorzec ikonograficzny łączący motywy zdobnicze, uwzględniający w zasadzie zawsze następujące grupy tematyczne:

1. kafle herbowe $z$ herbami państwowymi, ziemskimi, herbami Kapituły Gnieźnieńskiej i dostojników kościelnych, herbami rodowymi;

2. kafle zdobione motywami religijnymi, przede wszystkim scenami ze Starego i Nowego Testamentu, postaciami świętych, symbolami religijnymi;

3. kafle ze scenami z życia dworskiego - polowania, król spieszony i na koniu, zaślubiny, tańce, postacie dworzan, halabardnicy i rycerze itp.;

4. kafle z wyobrażeniami zwierząt i stworów fantastycznych;

5. kafle z motywami epickimi i satyrycznymi ilustrujące znane utwory literackie i opowieści ludowe;

6. kafle z motywami geometrycznymi i architektonicznymi;

7. kafle z motywami florystycznymi. 


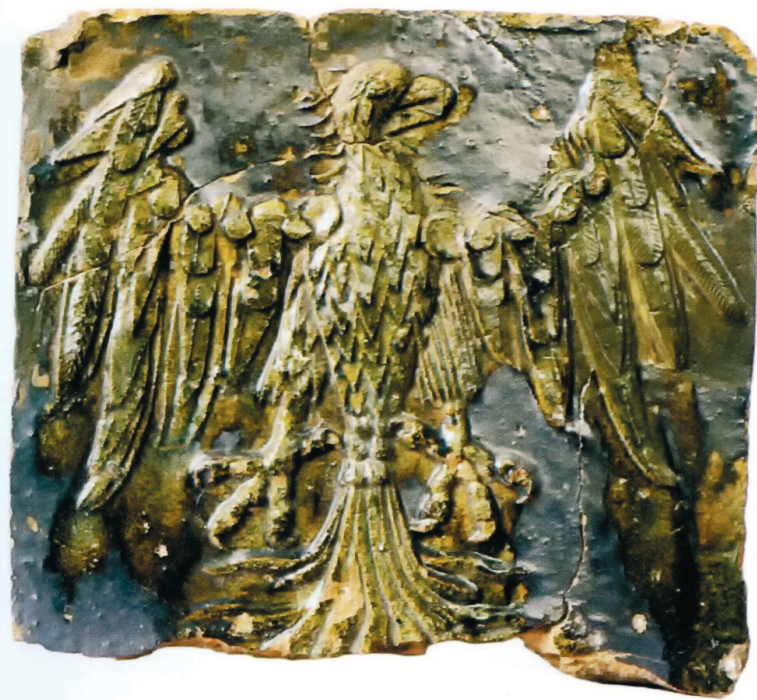

Ryc. 1. Jankowo Dolne, woj. wielkopolskie. Kafel z herbem Orzeł Biały, 2. ćwierć XV wieku (wg Janiak 2003)

Fig. 1. Jankowo Dolne, Wielkopolskie province. Tile with the White Eagle coat of arms, $2^{\text {nd }}$ quarter of $15^{\text {th }}$ century (after Janiak 2003)

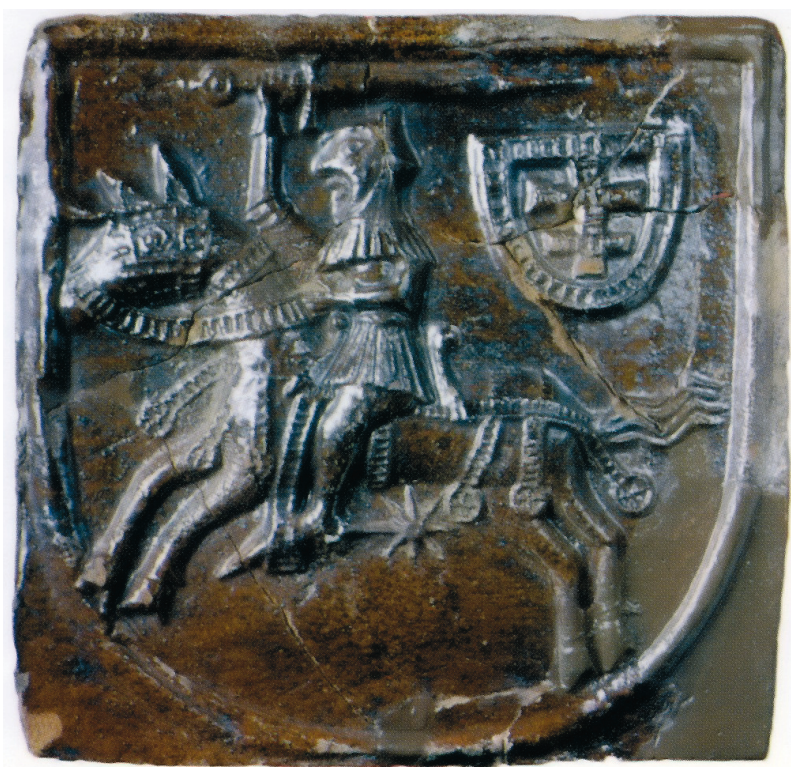

Ryc. 2. Jankowo Dolne, woj. wielkopolskie. Kafel z herbem Pogoń, 2. ćwierć XV wieku (wg Janiak 2003)

Fig. 2. Jankowo Dolne, Wielkopolskie province. Tile with the Pahonia coat of arms, $2^{\text {nd }}$ quarter of $15^{\text {th }}$ century (after Janiak 2003) 


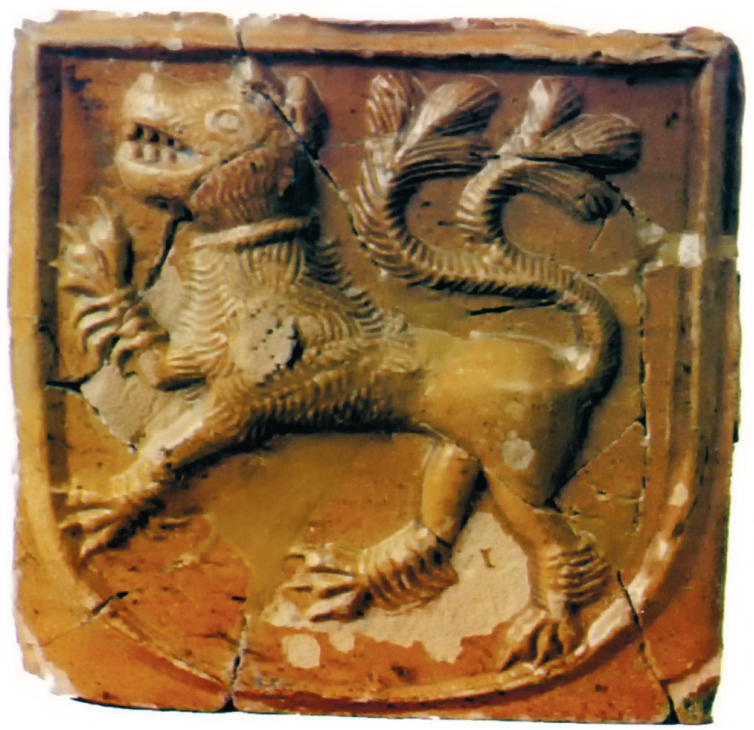

Ryc. 3. Jankowo Dolne, woj. wielkopolskie. Kafel z herbem Lewart, 2. ćwierć XV wieku (wg Janiak 2003)

Fig. 3. Jankowo Dolne, Wielkopolskie province. Tile with Lewart coat of arms, $2^{\text {nd }}$ quarter of $15^{\text {th }}$ century (after Janiak 2003)

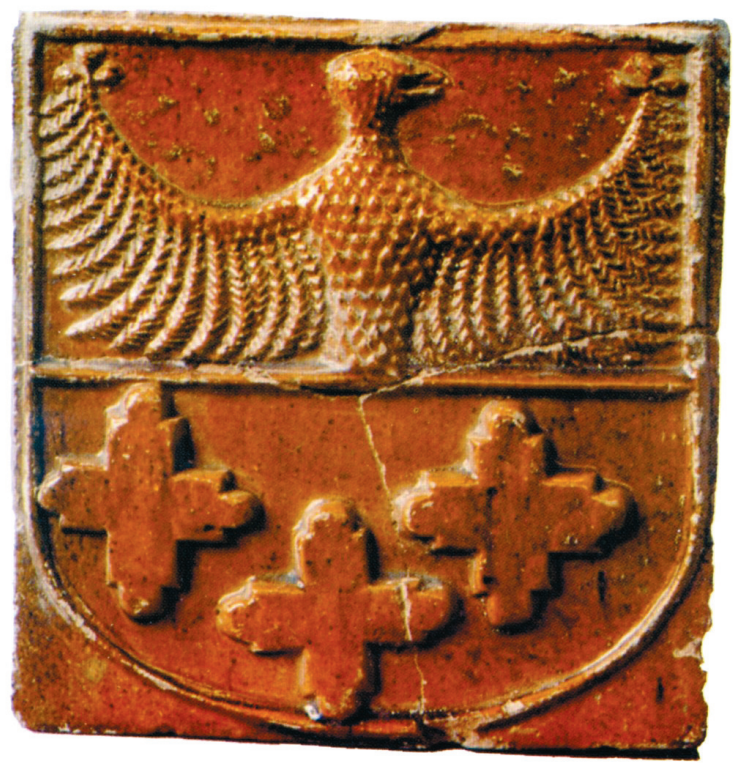

Ryc. 4. Jankowo Dolne, woj. wielkopolskie. Kafel z herbem Sulima, 2. ćwierć XV wieku (wg Janiak 2003)

Fig. 4. Jankowo Dolne, Wielkopolskie province. Tile with Sulima coat of arms, $2^{\text {nd }}$ quarter of $15^{\text {th }}$ century after (after Janiak 2003) 


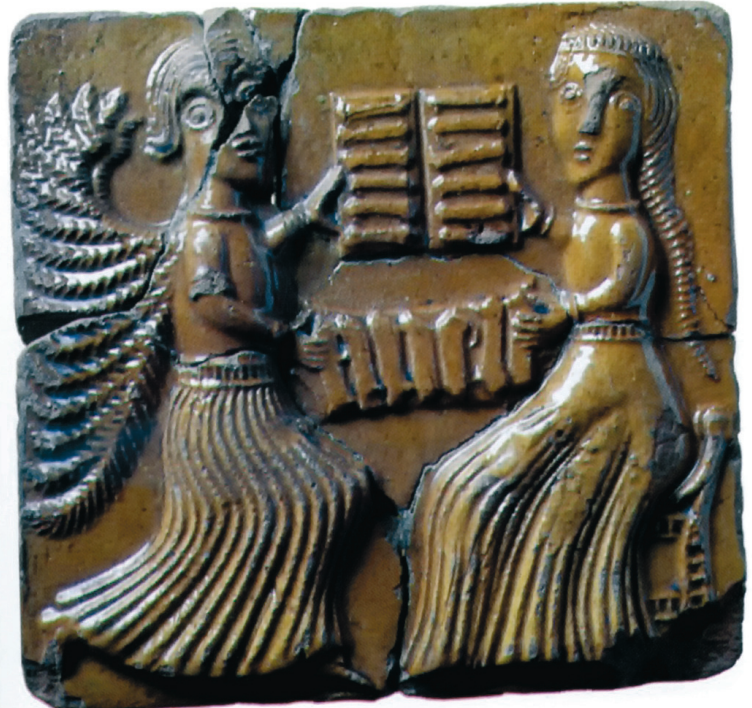

Ryc. 5. Jankowo Dolne, woj. wielkopolskie. Kafel z przedstawieniem Zwiastowania, 2. ćwierć XV w. (wg Janiak 2003)

Fig. 5. Jankowo Dolne, Wielkopolskie province. Tile with the Annunciation scene, $2^{\text {nd }}$ quarter of $15^{\text {th }}$ century (after Janiak 2003)

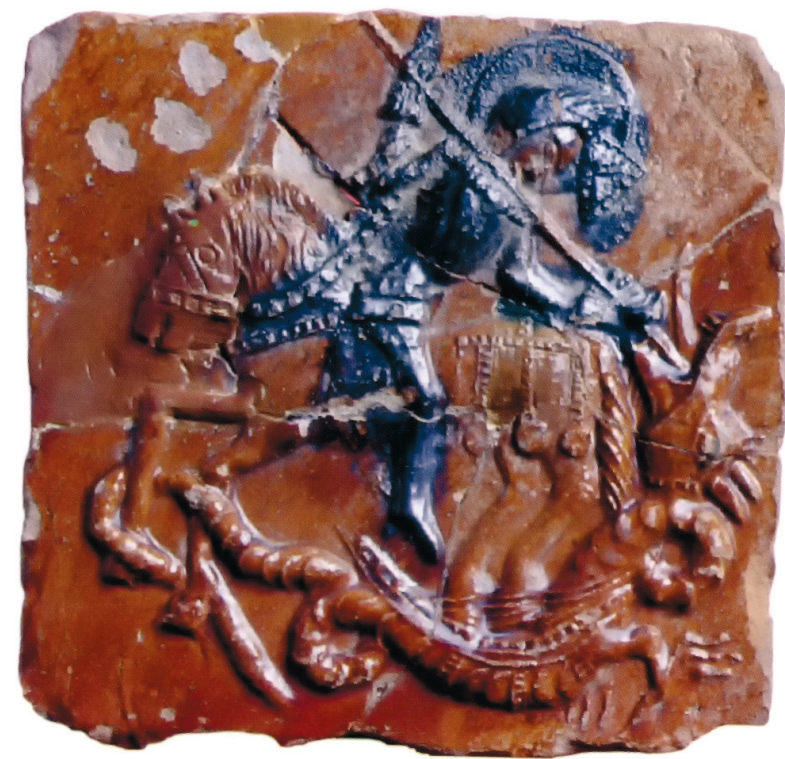

Ryc. 6. Jankowo Dolne, woj. wielkopolskie. Kafel z przedstawieniem św. Jerzego, 2. ćwierć XV wieku (wg Janiak 2003)

Fig. 6. Jankowo Dolne, Wielkopolskie province. Tile with an image of St. George, $2^{\text {nd }}$ quarter of $15^{\text {th }}$ century (after Janiak 2003) 


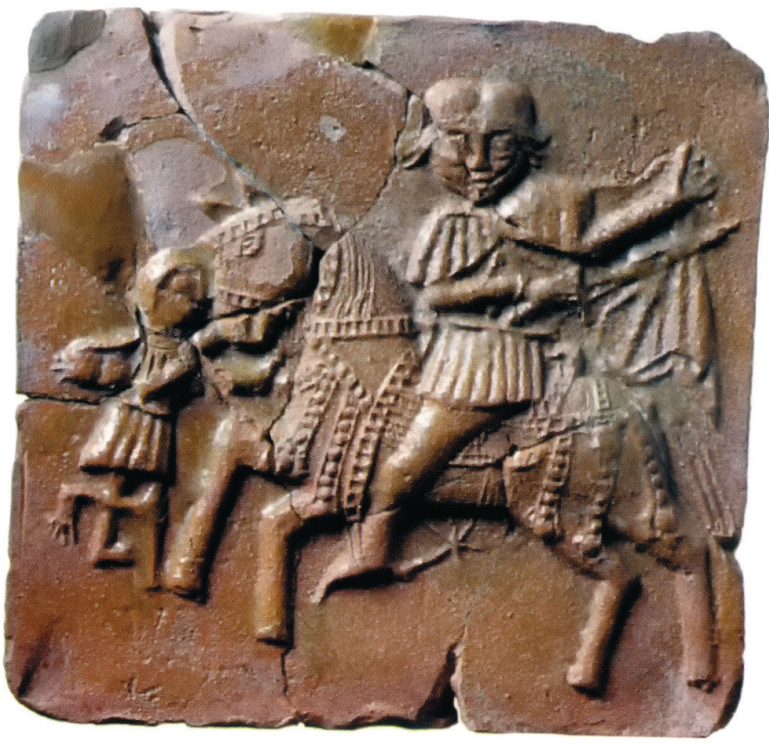

Ryc. 7. Jankowo Dolne, woj. wielkopolskie. Kafel z przedstawieniem św. Marcina, 2. ćwierć XV wieku (wg Janiak 2003)

Fig. 7. Jankowo Dolne, Wielkopolskie province. Tile with an image of St. Martin, $2^{\text {nd }}$ quarter of $15^{\text {th }}$ century (after Janiak 2003)

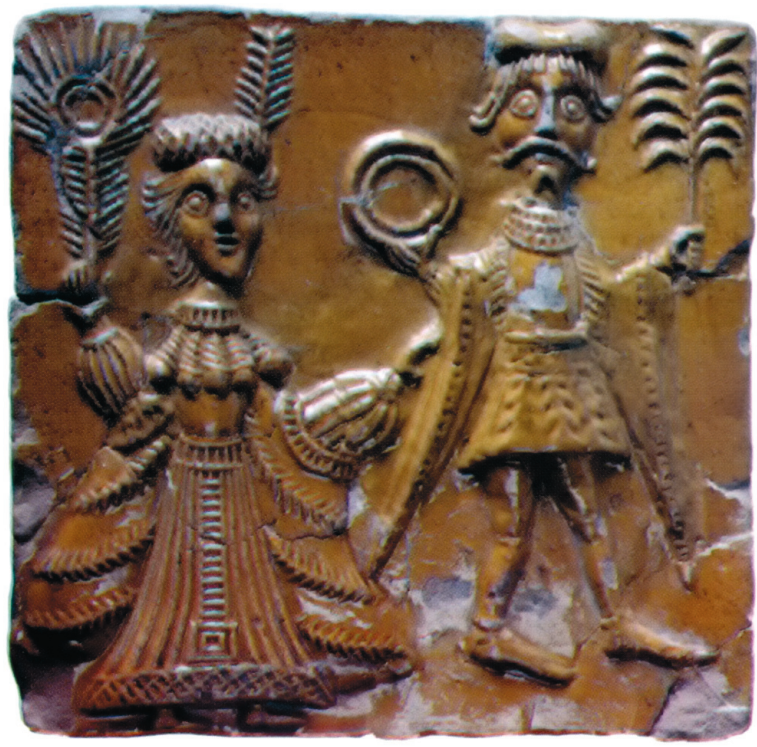

Ryc. 8. Jankowo Dolne, woj. wielkopolskie. Kafel z przedstawieniem zaślubin, 2. ćwierć XV wieku (wg Janiak 2003)

Fig. 8. Jankowo Dolne, Wielkopolskie province. Tile with a wedding scene $2^{\text {nd }}$ quarter of $15^{\text {th }}$ century (after Janiak 2003) 
Z tego bogactwa treści ikonograficznych dotychczas baczniejszą uwagę badaczy zwróciły kafle z przedstawieniami herbów. Leszek Kajzer widzi konieczność włączenia ich jako „herbarzy ceramicznych, równoprawną kategorię źródeł historycznych, do przyszłych, nie tylko heraldycznych analiz kultury społeczeństwa polskiego schyłku wieków średnich" (Kajzer 2007, s. 30). Z kolei R. Grygiel kafle z przedstawieniami herbów identyfikował jako ,piece kaflowe typu rycerskiego", uznając za „wyraz programu ideowego rezydencji późnośredniowiecznej i nowożytnej na terenie Wielkopolski”" (Grygiel 2001, s. 219-251). Na podstawie podobnych kryteriów M. Żemigała wydziela wymieniany już „piec herbowy" (Żemigała 1987, s. 30-34). Jednak trudno z tak spójnych zespołów kafli wyodrębniać tylko egzemplarze z przedstawieniami herbów i tworzyć z nich, dość sztucznie, specjalne typy pieców. Czy zatem, w zależności od przeważającej liczby pozyskanych kafli mielibyśmy także piece typu „dworskiego” czy „religijnego"? Przy znacznej przypadkowości znalezisk w każdej sytuacji byłaby to nadinterpretacja.

Sądzę, że rzeczywistość przekraczała nasze obecne wyobrażenia. Spójrzmy na $\mathrm{XV}$-wieczny piec stawiany z ozdobnych, ornamentowanych kafli, jako na element całego ówczesnego wyposażenia wnętrza. Niewątpliwie był on włączony w ogólny program jego upiększania. Wcześniej funkcje te zapewne spełniały rozwieszane tkaniny i niewątpliwie malowidła ścienne. Interesująco wygląda zestawienie i porównanie tych możliwości zdobniczych.

Ze zrozumiałych względów polichromie zdobiące ściany reprezentacyjnych pomieszczeń zachowały się w niewielu przypadkach. Znamy je przede wszystkim ze Śląska (Karłowska-Kamzowa 1965, s. 27-93; 1984a, s. 79-107; 1991, s. 65-72; Chorowska 2003, s. 122-125, 213-215, 217-221); odkryto je w świetlicach i sieniach rycerskich wież mieszkalnych, w zamkach, domach kleru, ale także w kamienicach mieszczan we Wrocławiu i Świdnicy (Chorowska 2003, s. 124, 213, 217-220). Najbardziej znane malowidło z wieży w Siedlęcinie datowane jest na lata 40. XIV wieku; przedstawia ono św. Krzysztofa, patrona dobrej śmierci i wzoru chrześcijanina oraz sceny związane z rycerzem Okrągłego Stołu - Lancelotem z Jeziora. Zatem artysta połączył tematykę religijną z epickim romansem rycerskim (Witkowski 2002, s. 90-91). Kolejne malowidło, zachowane fragmentarycznie, pochodzi z wieży w Witkowie; przedstawia sceny pasyjne z widocznym poniżej, także częściowo zachowanym widokiem miasta i znakami identyfikowanymi ze św. Jerzym (Gumiński, Olszewski 1963 s. 312-314). Malowidło, według autorów datowane na 2. połowę XV wieku, ma charakter symboliczny i jest interpretowane jako zwycięstwo dobra nad złem.

We Wrocławiu i Świdnicy fragmenty figuralnych polichromii odkryto w kamienicach, co świadczy o tym, że domy patrycjuszowskie także zdobiono tego typu malowidłami. Niestety ze względu na jedynie częściowe ich zachowanie nie jest możliwa interpretacja (Chorowska 2003, s. 218). 
Obok scen o charakterze religijnym i epickim w ramach zdobienia ścian przedstawiano na nich również herby. Rozległą średniowieczną galerię odkryto w wielkiej sali zamku w Żarach na pograniczu Śląska i Łużyc (Witkowski 1995, s. 69-73). Zdaniem Jacka Witkowskiego mogło tam znajdować się około 90 herbów szlachty śląskiej, z których do chwili obecnej zachowały się 23. Szeroki na $45 \mathrm{~cm}$ fryz datowany jest na 2 . ćwierć XV wieku. Wspomniany autor uważa, że pierwowzorem dla tego typu zdobnictwa była tradycja wywodząca się ,ze zwyczaju zawieszania tarcz na ścianach auli palatiów wczesnośredniowiecznych"1. Zatem przedstawienie tak licznych herbów nie może być traktowane jako wywód genealogiczny właściciela zamku, ale raczej jako dokumentacja istniejącego związku lub stowarzyszenia szlachty z pogranicza Śląska i Łużyc. Na obecnym etapie badań J. Witkowski uznał, że jest to dla średniowiecznej szlachty tych ziem ostatni dowód przynależności do grona „rycerskich mężów” (Witkowski 1995, s. 73). Informacje o kolejnej galerii herbów i portretów z wrocławskiego pałacu biskupiego zachowała się jedynie w przekazach pisanych (Karłowska-Kamzowa 1965, s. 90). Wykonano ją w 1492 roku i miała obejmować portrety i herby królów i biskupów wrocławskich. Fragmenty czterech herbów odsłonięto w kamienicy przyrynkowej w Świdnicy, w tym jeden księstwa Świdnickiego, zaś we Wrocławiu, w kamienicy należącej do krakowskiej rodziny Bonerów w pachach sklepiennych zachowało się malowidło przedstawiające elementy geometryczne i florystyczne, jednak nie wiemy, jaki był główny motyw (Chorowska 2003, s. 219-220).

Ten bogaty i zróżnicowany sposób wzbogacania wystroju był również stosowany w reprezentacyjnych wnętrzach innych dzielnic kraju - na Wawelu w Krakowie, na zamku w Niedzicy, w domu wikariuszy w Wiślicy, w klasztorach w Lądzie i Czerwińsku, w domach mieszczańskich w Warszawie i Toruniu, na zamkach między innymi w Działdowie, Lidzbarku, Reszlu (Karłowska-Kamzowa 1984b, s. 202-239). Szczególnym przykładem jest jedna z miniatur w „Kodeksie Baltazara Behema”, przedstawiająca wykonywanie malowidła w świeckim wnętrzu oraz odkrycie polichromii w kamienicach krakowskich i toruńskich (Konecki, Małkiewiczówna 1984, s. 16). W jarocińskiej wieży, skąd pochodzi jeden z XV-wiecznych pieców, również znajduje się fragment tynku pokryty ozdobnym fryzem; niestety, nie wiemy jak wyglądało całe malowidło (Grygiel 1987, s. 8).

Tematem polichromii, poza galeriami herbów, były przedstawienia o tematyce religijnej, mające niejednokrotnie wymowę symboliczną. Ze zrozumiałych względów niewiele przetrwało ich we wnętrzach reprezentacyjnych i mieszkalnych. Znacznie więcej zachowało się w kościołach, klasztorach i budynkach publicznych - ratuszach (Gotyckie malarstwo 1984, s. 7-10). Alicja Karłowska-Kamzowa zwraca uwagę na religijny, ale także moralizatorski charakter malowideł ściennych, chociażby poprzez postaci męczenników - św. Barbary, św. Katarzyny, św. Jana

${ }^{1}$ Zwyczaj malowania galerii herbowych dotarł z Francji; poza nią podobne fryzy herbowe znane są także z Niemiec, Szwajcarii, Czech, w Polsce - z klasztoru cysterskiego w Lądzie (Witkowski 1995, s. 71-72). 
Chrzciciela czy patronów rycerstwa - św. Jerzego i św. Marcina, a także świeckich bohaterów ówczesnej epiki.

Znamienne, że tę samą tematykę przedstawień odnajdujemy wśród motywów ornamentacyjnych kafli z XV i początku XVI wieku. Niejednokrotnie jest ona nawet bardziej rozbudowana, co zapewne wynika z ilości zachowanych wyrobów. Niewątpliwie w grupie kafli „herbowych” należy dać pierwszeństwo herbom państwowym i ziemskim, kolejne to herby dostojników kościelnych i rycerskie/ /rodowe, nawet jeśli nie zawsze były związane z obiektem, na którym je odnaleziono. Zapewne analogicznie, jak J. Witkowski w przypadku kolekcji herbów z zamku w Żarach, nie należy odczytywać gotyckich „,herbarzy kaflowych”, jako wywodów genealogicznych właścicieli, ale jako znaki przynależności terytorialnej i grupowej. Podobne założenie trzeba też przyjąć w przypadku kafli o tematyce religijnej - stanowiły one manifestację przynależności do obowiązującego wyznania - rodzaj wyznania wiary. Do tej grupy należy także dołączyć kafle z przedstawieniami symboli religijnych i ilustracjami znanych opowieści mających niejednokrotnie wymowę moralizatorską, jak na przykład scena przedstawiająca modny wówczas motyw „Filis na Arystotelesie” znany z kafli, rzeźb gotyckich i z grafik (Dąbrowska 2010, s. 143-152). Fragment kafla z przedstawieniem Filis, datowany na 2. połowę XV wieku, pozyskano także w trakcie badań wieży w Siedlęcinie (Nocuń 2009, s. 174). Znalezisko to jest dość interesujące, ponieważ początkowo uważano, że wieżę ogrzewano za pomocą kominka (Chorowska, 2003, s. 122-125).

Przy takiej interpretacji ornamentyka pieców gotyckich wpisywałyby się w przyjęty całościowy artystyczny program ówczesnej rezydencji, byłaby jego składnikiem, który należałoby odczytywać jako wyraz identyfikacji terytorialnej, grupowej, religijnej i kulturowej (Jakimowicz 2001, s. 252-254). Dzięki temu, poszerzając interpretację artystycznej strony kafli XV-wiecznych, wzbogacamy także wiedzę o właścicielach i fundatorach rezydencji.

Pod koniec XV i na początku XVI wieku, za sprawą wyjazdów dostojników kościelnych i świeckich do Włoch oraz przyjazdów Włochów, do Polski przenikały, głównie do Krakowa i na dwór królewski, nowe prądy humanizmu włoskiego. Ważną rolę w ich adaptacji odegrał również przyszły król Zygmunt I. Zetknął się z nimi przebywając u brata Władysława Jagiellończyka w Budzie, która była już ważnym ośrodkiem propagującym renesans włoski. Zygmunt I po powrocie do Krakowa, zaprosił architektów-rzeźbiarzy, którzy przystąpili do przebudowy Wawelu. Powstawały nowe partie zamku z wystrojem i wyposażeniem w duchu sztuki renesansu. Między innymi król zlecił odbudowę skrzydła zachodniego, które częściowo spłonęło, a w nim około 1505 roku polecił umieścić nowy piec. Stanął on, według ustaleń Marii Piątkiewicz-Dereniowej (1960a, s. 346) w skrzydle przeznaczonym na mieszkanie Elżbiety królowej-matki. Zygmunt na zamku w Budzie miał możliwość zapoznać się z piecami stawianymi z kafli zdobionych 
wyrazistym, bogatym ornamentem i pokrytych wielobarwnymi polewami. Piec taki z portretowymi kaflami przedstawiającymi króla Macieja Korwina i jego małżonkę Beatrycze postawiono tam w 1480 roku (Holl 2003, s. 255-272; Piątkiewicz-Dereniowa 1960a, s. 344-346). Najprawdopodobniej Zygmunt sprowadził do Krakowa również rzemieślników produkujących kafle, z których stawiano piece wyposażające nowe wnętrza. Z kafli pozyskanych w trakcie badań prowadzonych na terenie Wawelu zrekonstruowano jeden z takich pieców (ryc. 9) (Piątkiewicz-Dereniowa 1960b, s. 331-332). Miał on prostopadłościenną część paleniskową i cylindryczną nadstawę. Niestety, cytowana badaczka nie dysponowała pełnym zestawem kafli (Piątkiewicz-Dereniowa 1960a, s. 303-308), ale posługując się analogiami austriackimi i węgierskimi w części paleniskowej wykorzystała kafle zdobione stylizowanymi motywami roślinnymi, zaś w nadstawie w jednej wersji portretowe przedstawienie starego króla, w drugiej młodego władcy, w trzeciej zaś połączyła oba przedstawienia ${ }^{2}$. Jako fryz wieńczący M. Piątkiewicz-Dereniowa zaproponowała kafle $\mathrm{z}$ aniołem tarczownikiem podtrzymującym tarczę herbową z przedstawieniem Orła Białego. Również na narożnikach części paleniskowej umieściła nasadniki z aniołami trzymającymi analogiczne tarcze herbowe (ryc. 10). W zespole kafli znajdowały się również egzemplarze z portretami młodego dworzanina, halabardnika, ażurowe zdobione maswerkami. Wydaje się, że wszystkie mogły być użyte do budowy rekonstruowanej nadstawy, a wówczas bogatszy wystrój pieca bardziej zbliżałby go do innych obiektów z tego czasu, na przykład oryginalnego, z 1501 roku, zachowanego w tzw. Złotej Komnacie na zamku w Salzburgu (Piątkiewicz-Dereniowa 1960a, ryc. 51). Jego dolna skrzynia również była zbudowana z kafli zdobionych stylizowanymi kwiatami, zaś w górnej wykorzystano kafle o bogatym plastycznym ornamencie prezentującym tematykę religijną. Jak ustaliła M. Piątkiewicz-Dereniowa piec wawelski postawiono na polecenie króla Zygmunta I w komnacie królowej Elżbiety. Miało to miejsce zapewne w 1505 roku, czyli jeszcze za życia królowej. Jako starego króla sportretowano małżonka Kazimierza Jagiellończyka, a jako młodego Jana Olbrachta (ryc. 11). Pierwowzorem miały być postaci ze Statutów Łaskiego (Piątkiewicz-Dereniowa 1960a, s 312-314). Wszystkie kafle charakteryzuje jednolity, głęboki relief i zróżnicowana gama kolorystyczna zastosowanych polew - na obramieniu zielona, w tle jaśniejsza, zaś postacie i rozety są wielobarwne. Rozwiązanie konstrukcyjne pieca z cylindryczną nadstawą i prostopadłościenną częścią paleniskową dla wczesnego renesansu stało się typowe, zwłaszcza w kręgu związanym z dworem krakowskim. Wskazują na to liczne naśladownictwa bryły pieca i budowa kafli dostosowana do konieczności zestawiania na planie koła, natomiast nie powtórzono zestawu kafli z portretami królów.

Zwraca uwagę wystrój pieca przeznaczonego do komnat królowej, który - jak można przypuszczać - poprzez fakt umieszczenia kafli portretowych męża i syna

${ }^{2}$ Twarz jest wzorowana na nagrobku Jana Olbrachta, zaś postać na portrecie Aleksandra ze Statutu Łaskiego. 
w zamyśle Zygmunta I stanowił rodzaj hołdu złożonego królowej Elżbiecie - żonie króla Kazimierza Jagiellończyka i matce królów - Władysława, Jana Olbrachta, Aleksandra i Zygmunta I. Wśród kafli wykorzystanych do budowy dolnej części pieca znajdujemy motyw, który również mógł mieć wymowę symboliczną. Na jednym z nich za pomocą wyraźnego modelunku przedstawiono wypukły pierścień zbliżony do rozety, który w środku ma owalne w zarysie wgłębienie podzielone na części. Na jednej z nich widoczne są drobne kuliste ziarenka (Piątkiewicz-Dereniowa 1960a, s. 323). Tyle mówi nam opis autorki opracowania - M. Piątkiewicz-Dereniowej, natomiast przy bezpośrednim oglądzie kafla z dużą dozą prawdopodobieństwa można przyjąć, że owe kuliste ziarenka to owoce granatu, które symbolizują płodność i pełnię życia (Forstner 1990, s. 164), co w zestawieniu z domniemaną wymową ikonograficzną górnej części pieca byłoby uzasadnione i zgodne z osobą królowej. Ta część grzejnika, poza barwnymi polewami była dodatkowo złocona nakładanymi płatkami złota, które wzbogacały jego ozdobność. Wzbudził on zachwyt późniejszego panegirysty Bony - Neapolitańczyka Partenopeusa, który w 1518 roku przybywając w orszaku ślubnym, w wierszu poświęconym uroczystościom weselnym między innymi napisał, że „piece złocone jeszcze tam były" (Piątkiewicz-Dereniowa 1960a, s. 342). Warto także zwrócić uwagę, że na egzemplarzach z fryzu wieńczącego przedstawiono jedynie Orła Białego - godło państwa umieszczone również w narożnikach na tarczach podtrzymywanych przez anioła tarczownika, co w zestawieniu z licznymi kaflami herbowymi z innych zespołów piecowych tego czasu wydaje się mieć szczególne znaczenie i podkreśla wyjątkowość tego obiektu. W kolejnym odtworzonym piecu wawelskim, stawianym przed połową XVI wieku, umieszczono jedynie herb Królestwa Polskiego z inicjałem S (Sigismundus) i Bony Sforzy, co wpisywało się w program genealogiczno-heraldyczny Wawelu, realizowany przez króla Zygmunta I (Morka 2006, s. 89-113). Nie miał on, jak się wydaje, takiej wymowy symbolicznej jak piec „Z królami”, który mógł wyrażać osobisty stosunek syna do królowej matki.

Kolejny piec z okresu renesansu, który ma swoją wymowę ideologiczną został postawiony na przełomie 1545 i 1546 roku w gdańskim Dworze Artusa. Jak pisze Elżbieta Kilarska było to mistrzowskie dzieło Georga Stelzenera, które koncentrowało „,bogactwo przedstawionych na piecu treści, tak ściśle związanych z polityczną i religijną sytuacją Gdańska, jak i znacznej partii Europy znajdującej się pod panowaniem Habsburgów" (ryc. 12) (Kilarska 1992, s. 158). Na ścianach 12-metrowego pieca pomieszczono ponad cokołem w trzech zwężających się skrzyniach portrety 11 osób ze sfery władzy, między innymi Karola V z żoną Izabellą Portugalską, króla Ferdynanda z żoną Anną Jagiellonką, Ludwika II Jagiellończyka, elektora saskiego Fryderyka Mądrego, Jana Fryderyka Wspaniałomyślnego z żoną Sybillą księżniczką Juliaku, Kliwii i Bergu, Filipa Wspaniałomyślnego landgrafa Hesji (ryc. 13). Do wykonania matryc poszczególnych kafli posłużyły 
Ryc. 9. Kraków-Wawel. Piec z początku XVI w., rekonstrukcja M. Piątkiewicz-Dereniowa (wg Piątkiewicz-Dereniowa 1982)

Fig. 9. Kraków-Wawel. Stove from the beginning of $16^{\text {th }}$ century, reconstruction by M. Piątkiewicz-Dereniowa (after Piątkiewicz-Dereniowa 1982)

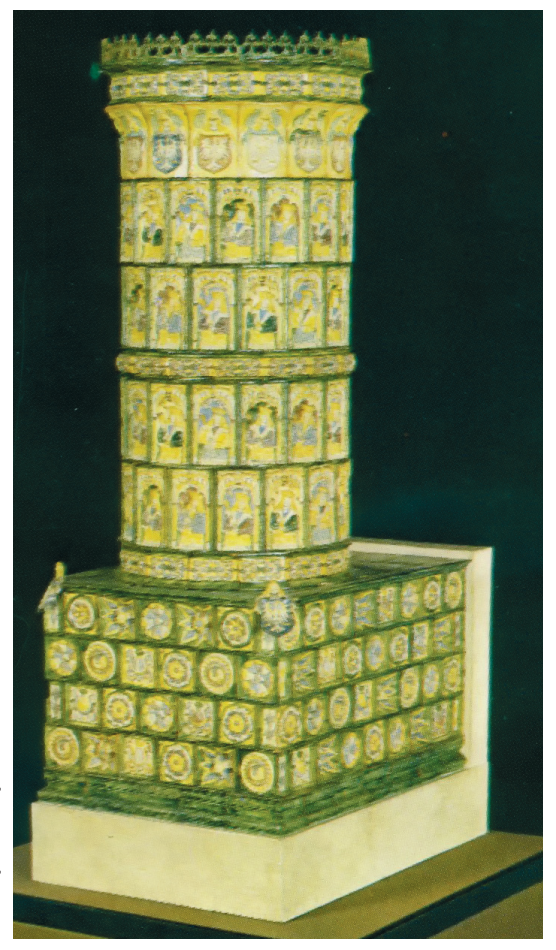

Ryc. 10. Kraków-Wawel. Kafel narożny $\mathrm{z}$ aniołem tarczownikiem, początek XVI w. (wg Piątkiewicz-Dereniowa 1982)

Fig. 10. Kraków-Wawel. Corner tile with an angel - a shield-bearer, the beginning of $16^{\text {th }}$ century (after Piątkiewicz-Dereniowa 1982)

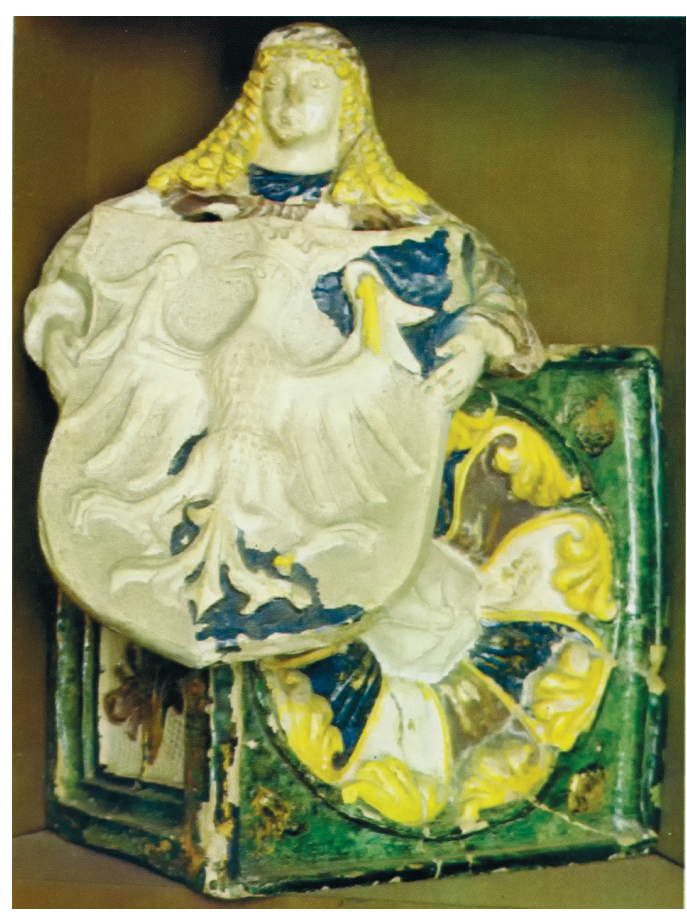



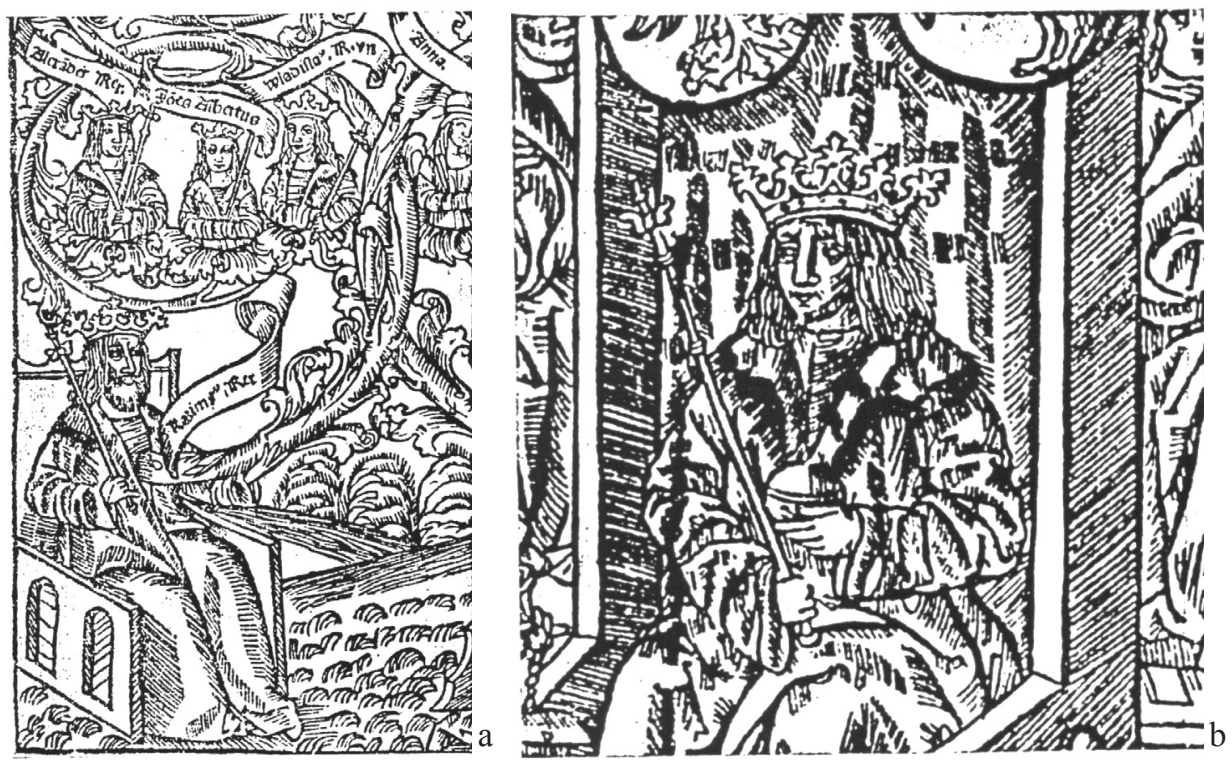

Ryc. 11. Drzeworyt ze „Statutów” Jana Łaskiego: a - Kazimierz Jagiellończyk i genealogia Jagiellonów; b - Jan Olbracht (wg Piątkiewicz-Dereniowa 1960a)

Fig. 11. Woodcut from Łaski's Statutes: a - Casimir IV Jagiellon and the Jagiellon genealogy; b - John I Albert (after Piątkiewicz-Dereniowa 1960a)

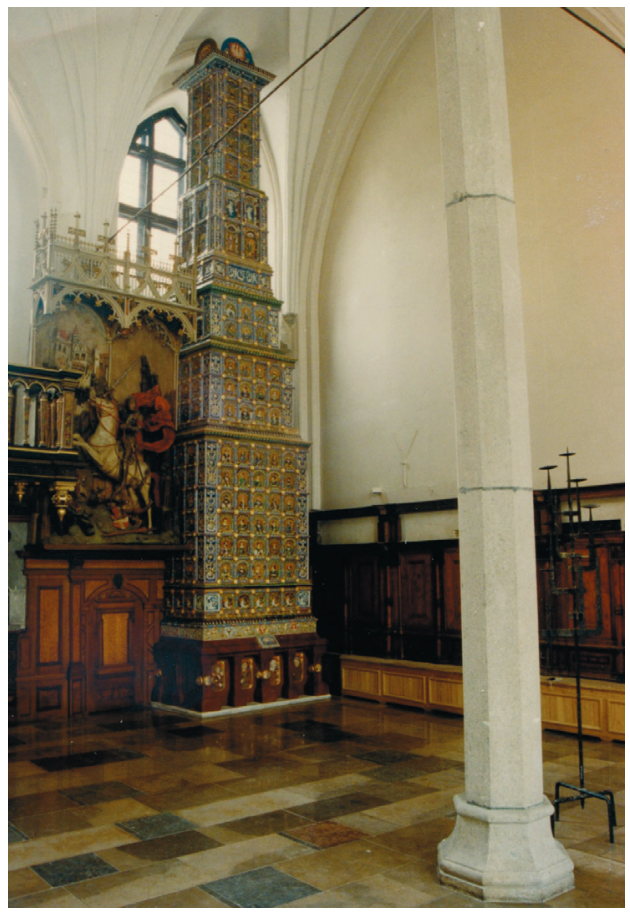

Ryc. 12. Gdańsk, Dwór Artusa. Piec z 1545/ /1546 roku, stan z 1996 roku (fot. B. Balcerzak)

Fig. 12. Gdańsk, The Artus Court. Stove from 1545/1546, state from 1996 (photo by B. Balcerzak) 

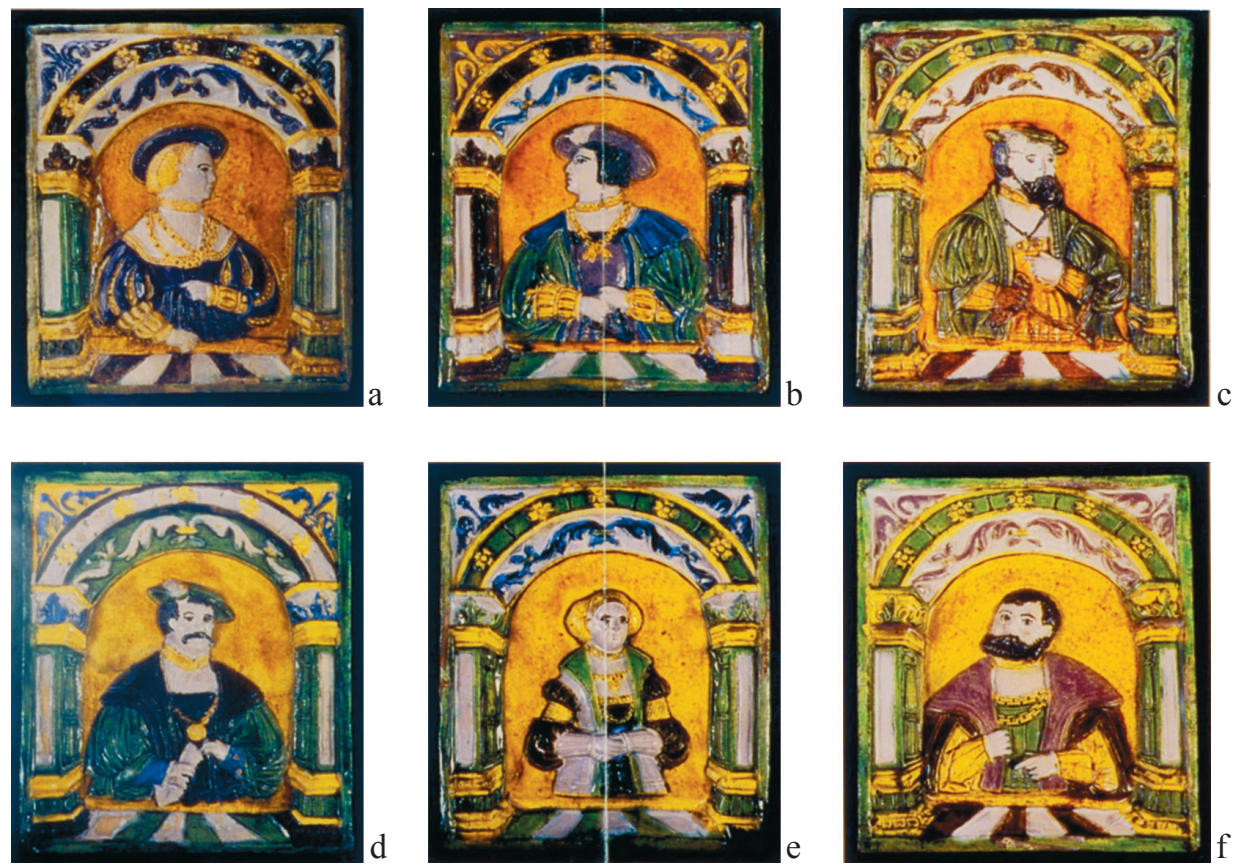

Ryc. 13. Gdańsk, Dwór Artusa. Kafle portretowe: a - Anna Jagiellonka; b-arcyksiążę Ferdynand I, mąż Anny Jagiellonki; c - Karol V, arcykatolicki rzymski cesarz narodu niemieckiego; d - Filip, landgraf Hesji; e - Sybilla księżniczka Juliaku, Kliwii i Bergu; f - Fryderyk Wspaniałomyślny, elektor saski, patron luteranizmu, małżonek Sybillii (wg Szypowscy b.r.w.)

Fig. 13. Gdańsk, The artus Court. Portrait tiles: $\mathrm{a}$ - Anna Jagiellon; $\mathrm{b}$ - archduke Ferdinand I, Anna Jagiellon's husband; c - Charles V, Holy Roman Emperor; d-Philip, Landgrave of Hesse; e - Sybil, Duchess of Juliak, Clivia and Berg; f - Frederic the Generous, duke of Saxe, Lutheranish patron, Sibil's husband (after Szypowscy b.r.w.)

niewątpliwie drzeworyty i miedzioryty znanych artystów (ryc. 14, 15). Kompozycja kolorystyczna zastosowanych polew zróżnicowała poszczególne portrety-kafle, dzięki czemu uniknięto monotonii obrazu. Zestawienie portretów czołowych władców katolickich obok wybitnych władców luterańskich było niewątpliwą demonstracją przekonań religijnych patrycjatu gdańskiego. Powyżej, na kolejnych skrzyniach, dla podkreślenia wymowy prezentowanych idei umieszczono personifikację planet - Księżyca i Wenus (ryc. 16: a) oraz cnót - Roztropności, Umiarkowania i Cierpliwości (ryc. 16: b), a na kolejnym kaflu Poznanie oraz personifikacje „dobrych bohaterek”. Natomiast w zwieńczeniu znajdowały się herby Prus Królewskich, Gdańska i szczecińskiej rodziny Loitzów, najprawdopodobniej fundatorów pieca. Skrzynie rozdzielały ozdobne gzymsy, a poszczególne kafle otaczały ornamentowane listewki i złocone rozetki. Poniżej, na kamiennym cokole 
umieszczono płaskorzeźby przedstawiające przedstawicieli najniższych warstw społecznych - kuglarza, błazna, parę zakonników i parę wieśniaków. Piec stojący w centralnym punkcie miasta, w Dworze Artusa, przekazywał określoną ideologię, a jednocześnie był arcydziełem sztuki zduńskiej, przez wieki niezmiennie wzbudzającym zachwyt. Nazywany w XIX wieku królem pieców (Szypowscy b.r.w., s. 154) przetrwał do 1945 roku i po odtworzeniu w 1996 roku nadal przyciąga uwagę wielkością i bogactwem wystroju.

W okresie manieryzmu i wczesnego baroku piece nadal były ważnym źródłem ciepła i elementem wyposażenia, ale już w innej stylistyce sztuki zdobniczej. W całej bryle, zarówno w górnej, jak i dolnej skrzyni, kafle były zdobione identycznymi, na ogół stylizowanymi motywami roślinnymi. Najbardziej popularna była tak zwana maureska skomponowana w kwadracie ze stylizowanych wici roślinnych, wypełniająca całą powierzchnię kafla, a także ornament kontynuacyjny obejmujący kilka kafli. Pokrywano je polewą białą na reliefie i granatową lub ciemnoniebieską w tle. W innych odmianach te same motywy glazurowano na zielono. Na połączeniu części paleniskowej i grzewczej pieca umieszczano fryzy i kafle gzymsowe ze scenami polowań, jednorożców, delfinów adorujących drzewko życia, a w eksponowanych częściach, w górnych ozdobnych gzymsach osadzano egzemplarze z przedstawieniami herbów. Były to przede wszystkim herby rodowe właścicieli, ale znane są również przykłady herbów ziemskich i państwowych, na przykład na piecu z Zamku Królewskiego w Warszawie, z kamienicy Hetmańskiej w Krakowie czy z rezydencji w Modliszewicach, Kielcach, Nowym Mieście (Dąbrowska 1994, ryc. 8-9; 2007, ryc. 12-14).

Wyjątkowym przykładem wśród pieców z początku XVII wieku jest grzejnik zrekonstruowany z kafli odkrytych w trakcie badań wykopaliskowych na zamku w Tykocinie (Dąbrowska 2006, s. 70-75) ${ }^{3}$. Obiekt, leżący w dolinie Narwi, zaliczany jest do grupy największych zamków nizinnych. Poprzedzał go średniowieczny gród drewniano-ziemny, należący do litewskiej rodziny Gasztołdów. Kolejny, murowany obiekt powstał za czasów Zygmunta Augusta, następnie przebudowano go na początku XVII wieku, kiedy starostą tykocińskim został Krzysztof Wiesiołowski. O wyglądzie zamku tykocińskiego z tego czasu w zasadzie niewiele wiadomo; na podstawie badań archeologicznych możliwe było ustalenie jedynie jego wielkości i rozplanowania. Musiała to być jednak okazała rezydencja, skoro Szymon Starowolski w roku 1632 wymieniając zamek tykociński określił go jako „wytworny i ozdobiony przez Krzysztofa Wiesiołowskiego świetną architekturą" (Maroszek 2000, s. 330). Jednak wśród reliktów odsłoniętych w wyniku badań archeologicznych brakuje elementów tej „świetnej architektury”. Pozyskano natomiast liczący kilka tysięcy zbiór kafli, pochodzących z pieców stojących we wnętrzach zamkowych, które w większości,

${ }^{3}$ Badaniami prowadzonymi w latach 60 . XX wieku kierował prof. Jerzy Kruppé, zaś w latach 90. mgr Magdalena Bis i mgr Wojciech Bis. 

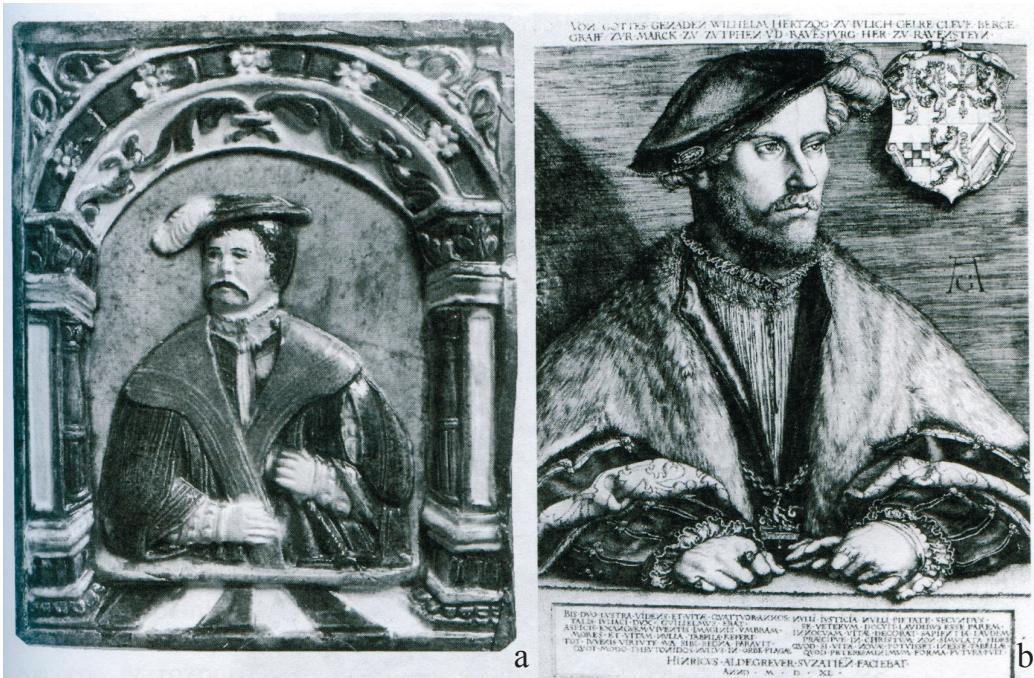

Ryc. 14. Gdańsk, Dwór Artusa. Kafel portretowy - Wilhelm książę Kliwii i Bergu (a) oraz domniemany pierwowzór - miedzioryt Hansa Aldegravera z 1540 roku (b) (wg Kilarska 1992)

Fig. 14. Gdańsk, The Artus Court. Portrait tile - William, duke of Clivia and Berg (a) and supposed original version - copperplate engraving by Hans Aldegraver from 1540 (b) (after Kilarska 1992)
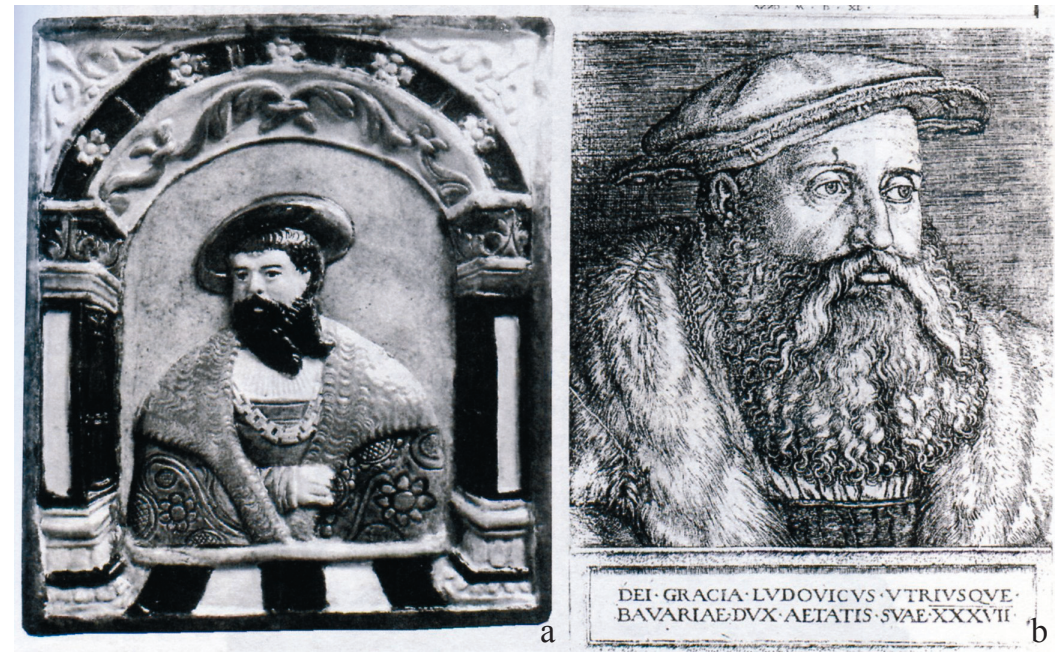

Ryc. 15. Gdańsk, Dwór Artusa. Kafel portretowy - książę Ludwik Bawarski (a) oraz domniemany pierwowzór - drzeworyt Bartela Behama z 1541 roku (b) (wg Kilarska 1992)

Fig. 15. Gdańsk, The Artus Court. Portrait tile - Duke Louis IV the Bavarian (a) and supposed original version - woodcut by Bartel Beham from 1541 (b) (after Kilarska 1992) 

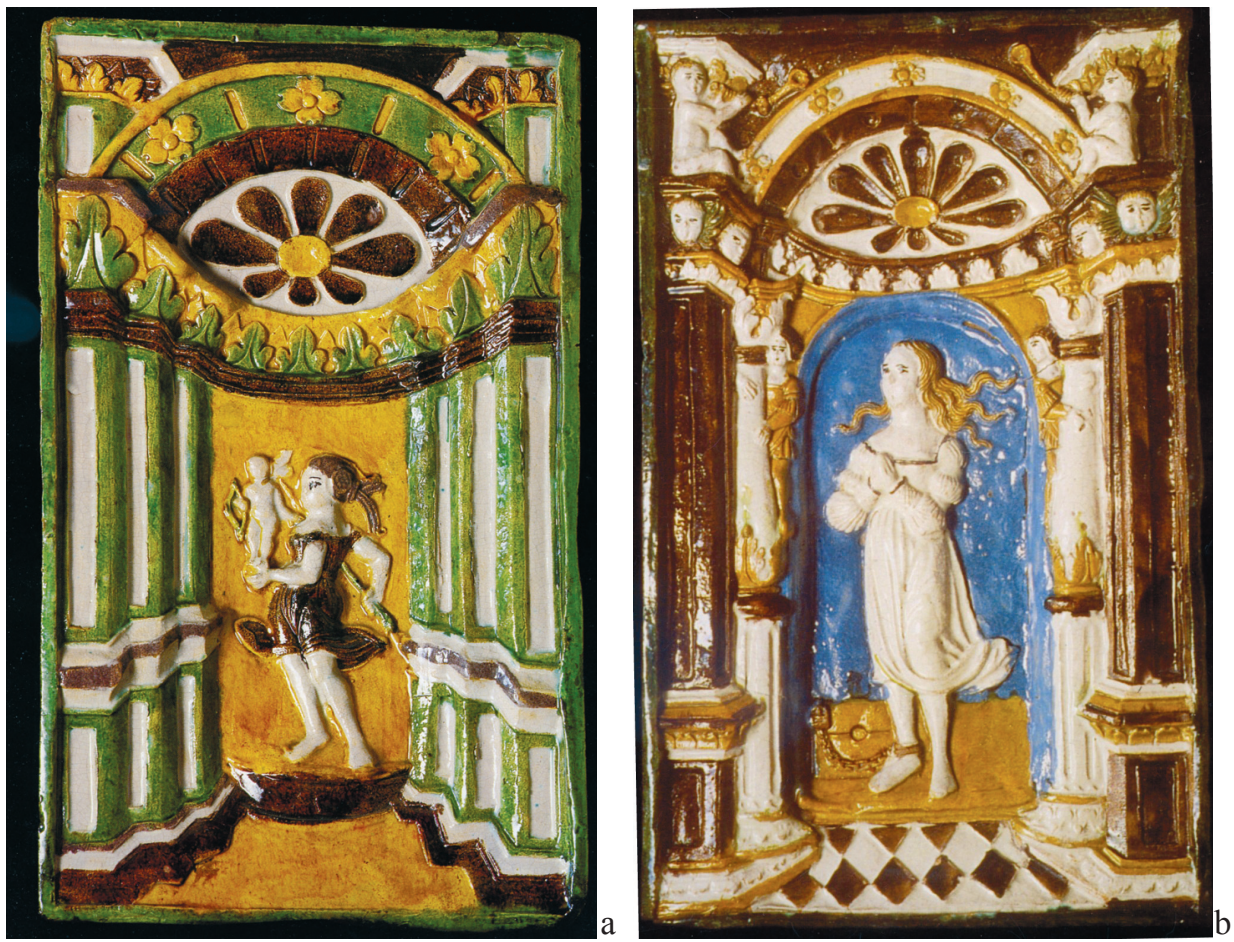

Ryc. 16. Gdańsk, Dwór Artusa. Kafle z przedstawieniami Wenus (a) i Cierpliwości (b) (wg Szypowscy b.r.w.)

Fig. 16. Gdańsk, The Artus Court. Tiles with Venus (a) and Patience images (b) (after Szypowscy b.r.w.)

na podstawie cech stylistycznych ornamentów można było uznać za pozostałości pieców stawianych na początku XVII wieku. Zatem niewątpliwie stanowiły część wyposażania zamku, powstałego na zlecenie Krzysztofa Wiesiołowskiego. Wśród nich wyróżniał się zespół kafli pokrytych biało-granatowymi polewami i zdobionych grubym, wyrazistym reliefem ${ }^{4}$. Głównym motywem powtarzanym na elementach zwieńczenia i wszystkich kaflach nie były motywy kwiatowe, ale herby odpowiadające rodowodowi Krzysztofa Wiesiołowskiego, starosty tykocińskiego w latach 1604-1637. Zestawione cztery herby projektant pieca umieścił w owalnej tarczy herbowej wzbogaconej labrami i otoczonej wieńcem z liści laurowych (ryc. 17). Pole górne heraldyczne prawe, ojczyste zajmuje Ogończyk - herb Piotra Wiesiołowskiego Młodszego (zmarłego w 1621 roku), syna Piotra Wiesiołowskiego Starszego (zmarłego w 1556 roku). Pole górne heraldyczne lewe, macierzyste to

${ }^{4}$ Zrekonstruowany piec w 2011 roku został postawiony w jednej z sal odtworzonego zamku w Tykocinie, obecnie należącego do prywatnego właściciela - Jacka Nazarko. Rekonstrukcję kafli i pieca wykonała dr Maria Dąbrowska, model fryzu dr Jacek Martusewicz, kafle wyprodukowano w firmie „Karny” w Białymstoku. 
Śreniawa - herb (bez krzyża) Zofii Lubomirskiej, żony Piotra Wiesiołowskiego Młodszego. Pole dolne heraldyczne prawe, babki ojczystej zajmuje herb Bogoria Katarzyny z Wołłowiczów Wiesiołowskiej, żony Piotra Starszego. Pole dolne heraldyczne lewe, babki macierzystej to herb Odrowąż Anny Pieniążkówny z Kuźlowy, matki Zofii Lubomirskiej, pierwszej żony Sebastiana Lubomirskiego, herbu Śreniawa (żył około lat 1539-16135). Tarcze herbowe przedstawione na elementach zwieńczenia dodatkowo zostały ozdobione stylizowanymi rogami obfitości i winnymi gronami, a kafle wypełniające niewielkimi stylizowanymi listkami umieszczonymi w narożnikach (ryc. 18: a). Na wąskich kaflach narożnych, zarówno z dolnej, jak i górnej części pieca również umieszczono stylizowane liście winnej latorośli i winne grona. Wnęki kafli narożnych z górnej skrzyni ozdobiono stylizowanym ornamentem okuciowym, który jest charakterystyczny dla sztuki zdobniczej 1. połowy XVII wieku (ryc. 18: c). Kafle gzymsowe z nadstawy pieca zdobione są wolimi oczkami i kostką - motywami przyniesionymi jeszcze ze sztuki antyku i często wykorzystywanymi w ornamentyce poziomych elementów konstrukcyjnych wielu stylów. Górny gzyms tworzą kafle z przestawieniem herm rozdzielanych motywami roślinnymi (ryc. 18: b), podkreślony od dołu fryzem zdobionym również ornamentem roślinnym.

$\mathrm{Na}$ podstawie charakterystycznych cech ornamentu, głównie owego wyrazistego reliefu oraz barw polew, a także cech technologicznych, z zespołem tym połączono 17 fragmentów kafli fryzowych z przedstawieniami scen walki (ryc. 19: a, 20). Wstępnie ustalono, że część walczących to rycerze w zbrojach o cechach zachodnioeuropejskich, część zaś, w zbrojach wschodnich, to wojownicy muzułmańscy. Ponieważ jest to - jak dotychczas - jedyne takie przedstawienie na kaflach, podstawowy problem polegał na identyfikacji sceny oraz ustaleniu jej pierwowzoru graficznego. W dalszej kolejności należało wykonać rekonstrukcję całego fryzu, który w piecu był osadzony powyżej gzymsu rozdzielającego skrzynie (ryc. 21, 22).

Zważywszy na rozbudowaną heraldykę Krzysztofa Wiesiołwskiego, uwiecznioną na kaflach z tykocińskiego pieca, pierwowzoru fryzu poszukiwano w powiązaniu z historią rodu Wiesiołowskich - udziału przodków w znaczących bitwach. Drugi kierunek poszukiwań nawiązywał do etosu rycerskości i sarmatyzmu - ideologii początku XVII wieku (Borowski 2001, s. 175-179); ten też okazał się tym właściwym. Pierwowzorów należało szukać w malarstwie batalistycznym, zdobywającym w tym czasie coraz większą popularność w całej Europie (Morka 1984, s. 210-256). W ten sposób dokumentowano prowadzone aktualnie walki, jednocześnie propagując treści symboliczne. Cechą charakterystyczną tego kierunku sztuki było powszechne korzystanie z graficznych pierwowzorów przedstawiających pojedyncze sceny lub osoby. Jedną z najwybitniejszych postaci

${ }^{5}$ Za pomoc w identyfikacji herbów dziękuję prof. Józefowi Maroszkowi z Uniwersytetu w Białymstoku. 


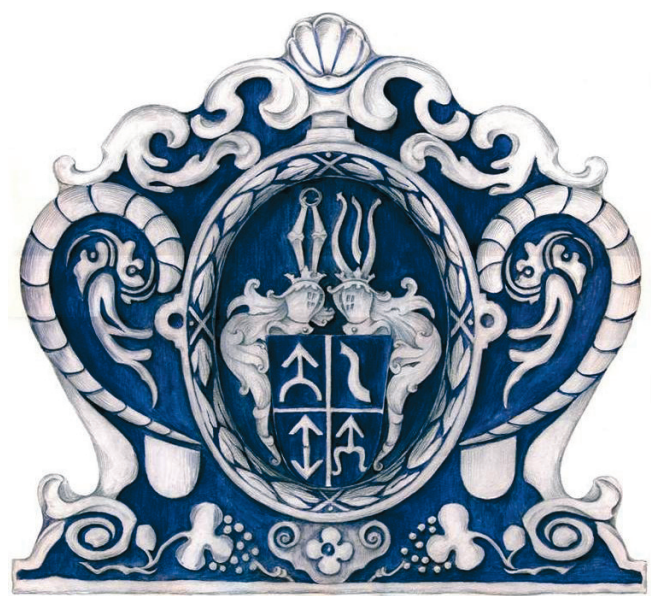

Ryc. 17. Tykocin, woj. podlaskie. Kafel wieńczący z początku XVII wieku - rekonstrukcja rysunkowa (oprac. M. Dąbrowska; rys. E. Gumińska)

Fig. 17. Tykocin, Podlaskie province. Apextile from the beginning of $17^{\text {th }}$ century - drawing reconstruction (elab. by M. Dąbrowska; drawing by E. Gumińska)
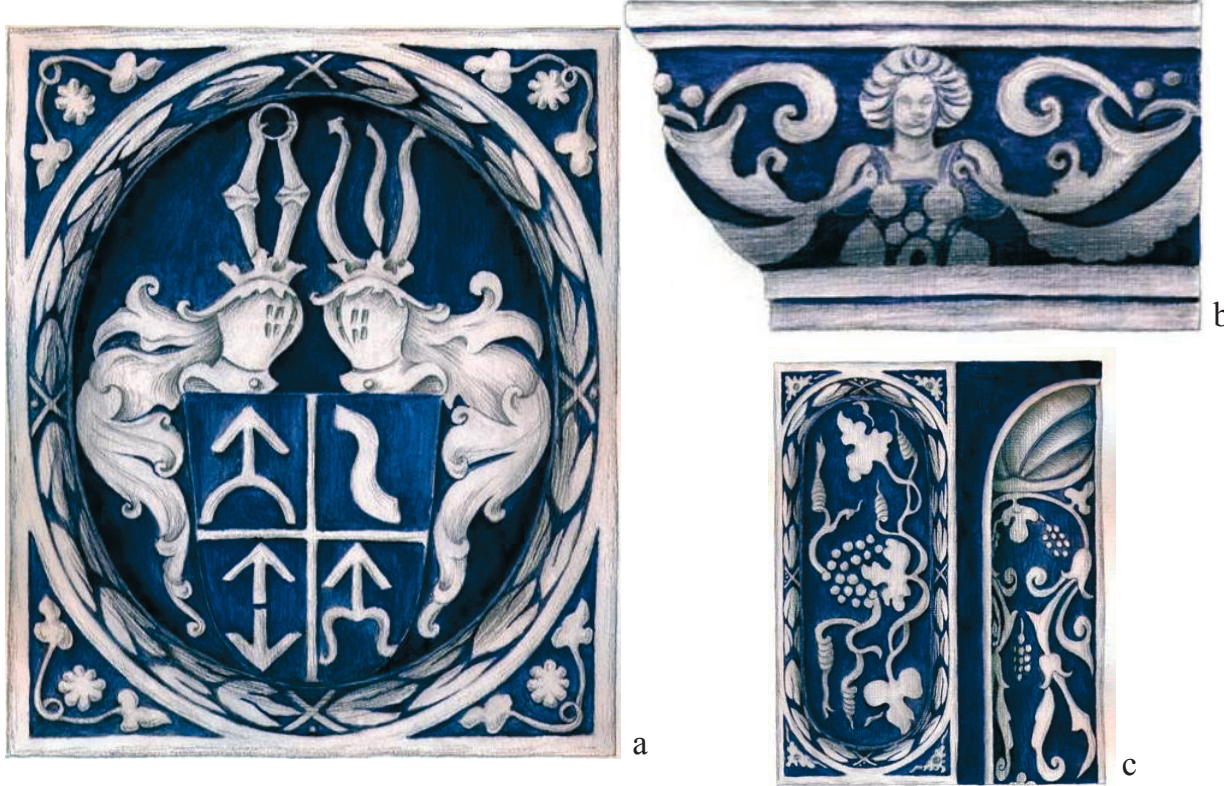

Ryc. 18. Tykocin, woj. podlaskie. Kafle z początku XVII wieku - rekonstrukcja rysunkowa kafli: a - wypełniający; b - gzymsowy; c - narożny (oprac. M. Dąbrowska; rys. E. Gumińska)

Fig. 18. Tykocin, Podlaskie province. Tiles from the beginning of $17^{\text {th }}$ century - drawing reconstruction: $\mathrm{a}$ - filling tile; $\mathrm{b}$ - cornice tile; $\mathrm{c}$ - corner tile (elab. by M. Dąbrowska; drawing by E. Gumińska) 

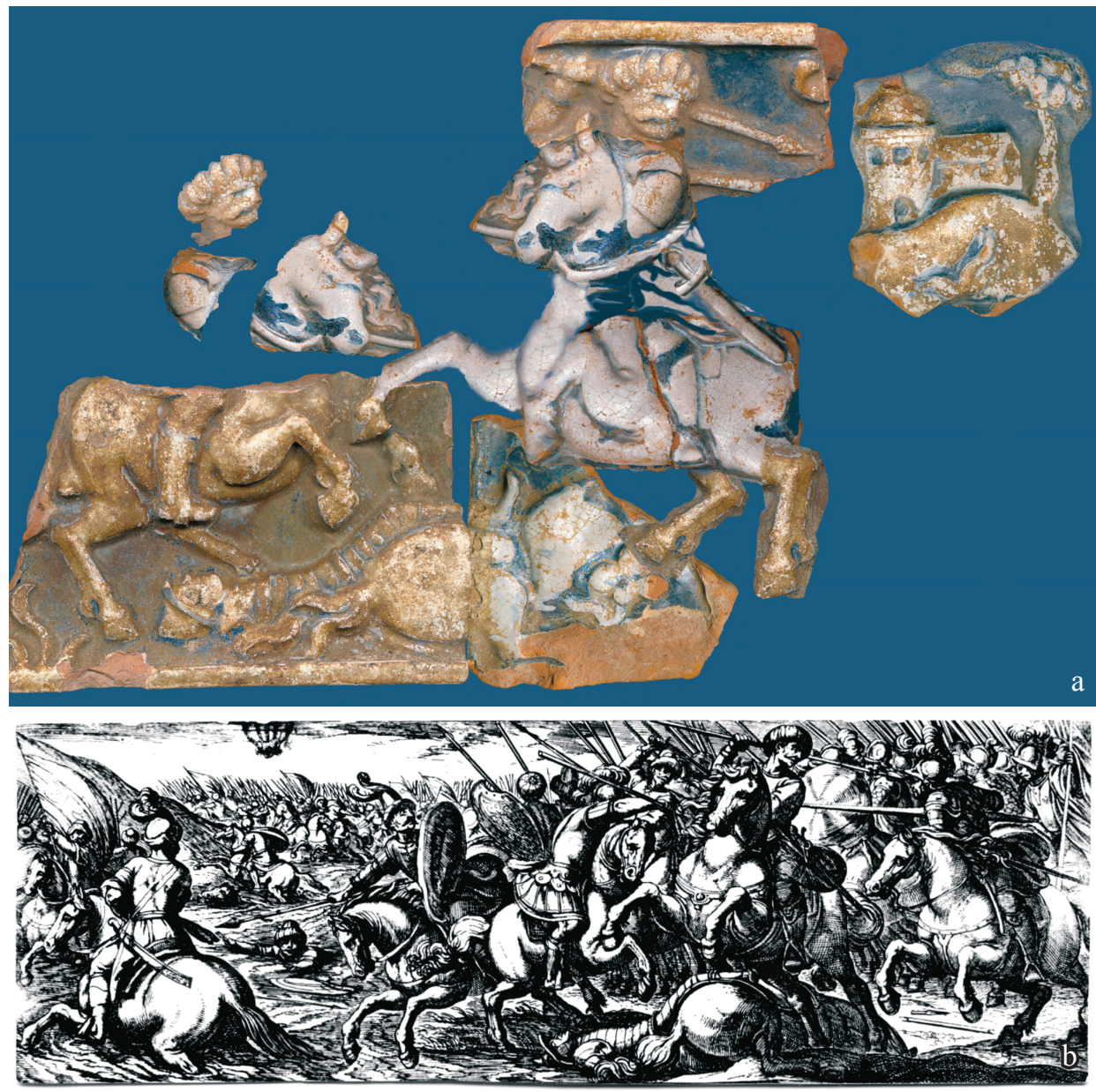

Ryc. 19. Tykocin, woj. podlaskie. Kafle z początku XVII wieku: a - fragmenty kafli z fryzu środkowego (foto W. Bis); b - Antonio Tempesta, akwaforta nr 969 (wg Morka 1984)

Fig. 19. Tykocin, Podlaskie province. Tiles from the beginning of $17^{\text {th }}$ century: a - tile fragments from middle frieze (photo by W. Bis); b - Antonio Tempesta, etching no 969 (after Morka 1984)

spośród twórców europejskich 1. połowy XVII wieku był Jan Stradanus, artysta pochodzący z Antwerpii, który jako rysownik-projektant dostarczał rysunki dla tkaczy gobelinów, ale też tworzył grafiki o bardzo zróżnicowanej tematyce. Największą popularnością cieszyły się jego kompozycje o tematyce batalistycznej i myśliwskiej, te ostatnie często także przedstawiane na XVII-wiecznych kaflach. Kontynuatorem kierunku batalistycznego, jak pisze Mieczysław Morka, był jego najwybitniejszy uczeń Antonio Tempesta, grafik florencki żyjący w latach 1555-1630. ,W jego dorobku liczącym prawie dwa tysiące grafik również dominuje 
tematyka wojenna. Tworzył setki kompozycji o skomplikowanych układach koni i jeźdźców oraz skłębionych grup walczącej jazdy i piechoty" (Morka 1984, s. 48). Artysta ten w 1599 roku wydał serię 10 akwafort o wymiarach 9,6 $\times 27,4 \mathrm{~cm}$, pt. „Libretti di batalie”. Wykorzystywali je zarówno malarze bataliści, jak i artyści wykonujący pojedyncze portrety konnych, przedstawiano je także jako tło scen bitewnych; zdaniem M. Morki posługiwali się nimi malarze w całej Europie (Morka 1984, s. 218-219). Jak wykazały badania korzystał z nich także twórca matryc kafli fryzowych z pieca tykocińskiego. Na dwóch kolejnych płytkach licowych znajdujemy przeniesione fragmenty dwóch akwafort nr 966 i nr 969. W pierwszej scenie rycerz chrześcijański atakowany jest przez wojownika muzułmańskiego (ryc. 19: a); atakujące spięte konie znajdują się nad leżącym na zadzie konia poległym rycerzu chrześcijańskim (akwaforta nr 969) (Morka 1984, il. 30). W scenie drugiej kopijnik przebija leżącego rycerza (ryc. 20) (akwaforta nr 966). Postaci odwzorowane są z dużą dokładnością, wiernie oddają napięcie i ekspresję prezentowanych zdarzeń. Ze zrozumiałych względów snycerz przygotowujący matryce pominął szczegóły drugiego planu, przedstawiając jako tło zameczek na wzniesieniu i drzewa, co też poniekąd jest zgodne z dalekim planem zaczerpniętym ze sceny na akwaforcie nr 966. Jak wykazały badania nie jest to przedstawienie konkretnych postaci lub zdarzeń związanych z historią rodu Wiesiołowskich, ale apoteoza etosu rycerstwa - mężnego i walecznego. Warto jednak przypomnieć, że pierwowzór atakującego rycerza chrześcijańskiego z pierwszej sceny został wykorzystany także w przedstawieniu Jana III Sobieskiego na obrazie Romeyn'a de Hooghe'a „Gloryfikacja Jana III na tle bitwy pod Chocimiem” jako wodza-jeźdźca prowadzącego oddział do ataku (Morka 1984, il. 26).

Analizując ikonografię całego pieca zwraca uwagę jego zwarte znaczenie symboliczne. Herby odwołują się do dumy rodowej, mają wykazać „dobrą sławę” Krzysztofa Wiesiołowskiego. Heraldykę rodu otaczają motywy rogów obfitości, będące symbolem płodność ziemi i odradzającego się bogactwa. Gałązki winnej latorośli umieszczone w narożnikach wypełniają tło, ale też mają podwójne znaczenie - są symbolem ofiary i płodności, zaś winne grona symbolizują Chrystusa i ofiarę, a więc nawiązują do tradycji chrześcijańskiej. Przekazane na piecu treści nawiązują do duchowej i umysłowej kultury Rzeczpospolitej szlacheckiej.

Piec tykociński jako symbol swoich czasów dołącza do wcześniej prezentowanych przykładów - pieców gotyckich, pieca wawelskiego i „króla pieców” z Dworu Artusa. Każdy z nich jest wyraźnym przekaźnikiem określonego programu ikonograficznego z wielkim kunsztem przedstawionego przez projektantów i twórców.

Piece kaflowe, które niewątpliwą były nowością w XIII i XIV wieku chyba już w XV stuleciu można uznać za tradycyjne, w pełni zaadaptowane urządzenie grzewcze. Natomiast ich funkcje zdobnicze od XIV do XVIII wieku zmieniały się ustawicznie, przekazując nowe treści, dzięki którym wzbogacamy naszą wiedzę o sztukach zdobniczych, nowych prądach, a także upodobaniach właścicieli. 

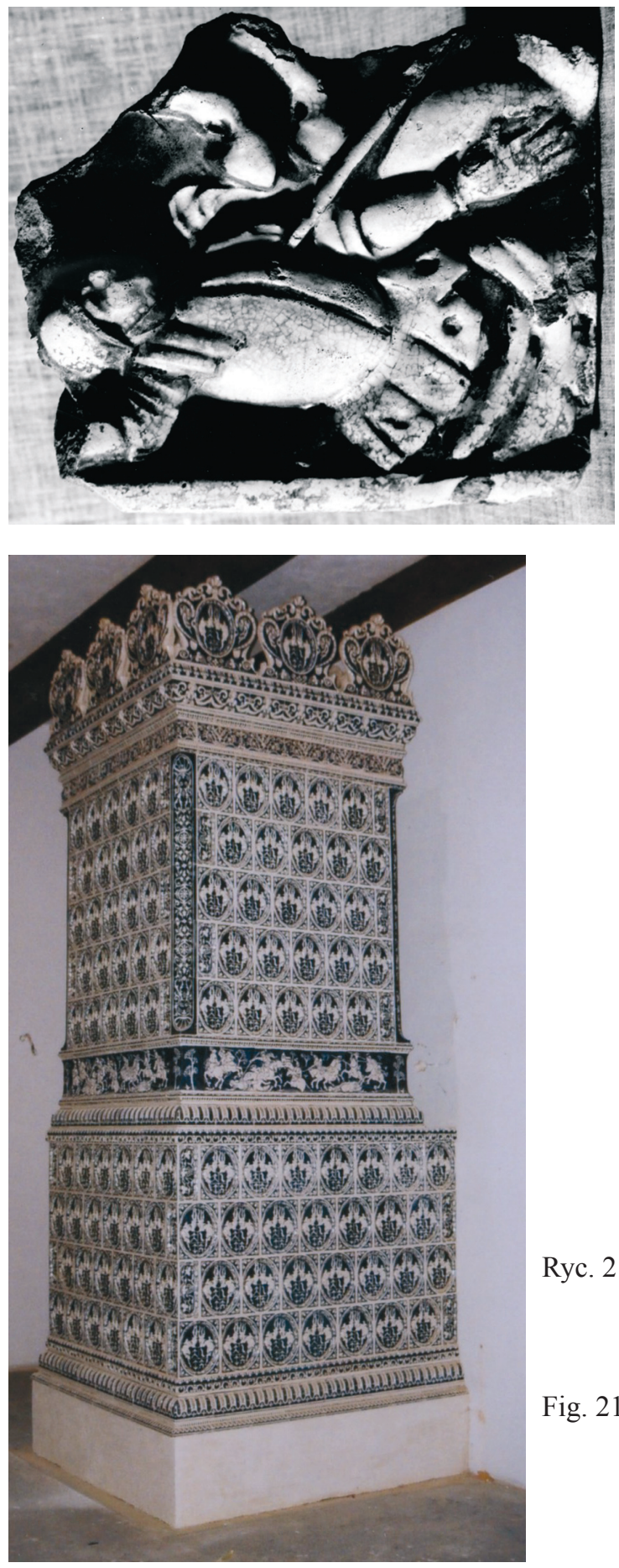

Ryc. 20. Tykocin, woj. podlaskie. Fragment kafla $\mathrm{z}$ drugiej części fryzu, początek XVII wieku (fot. A. Lipka)

Fig. 20. Tykocin, Podlaskie province. Tile fragment from the other frieze part, the beginning of $17^{\text {th }} \mathrm{c}$ (photo by A. Lipka)
Ryc. 21. Tykocin - zamek, woj. podlaskie. Piec z początku XVII wieku - rekonstrukcja (oprac. M. Dąbrowska; fot. W. Bis)

Fig. 21. Tykocin - castle, Podlaskie province. Stove from the beginning of $17^{\text {th }}$ century - reconstruction (elab. by M. Dąbrowska; photo by W. Bis) 

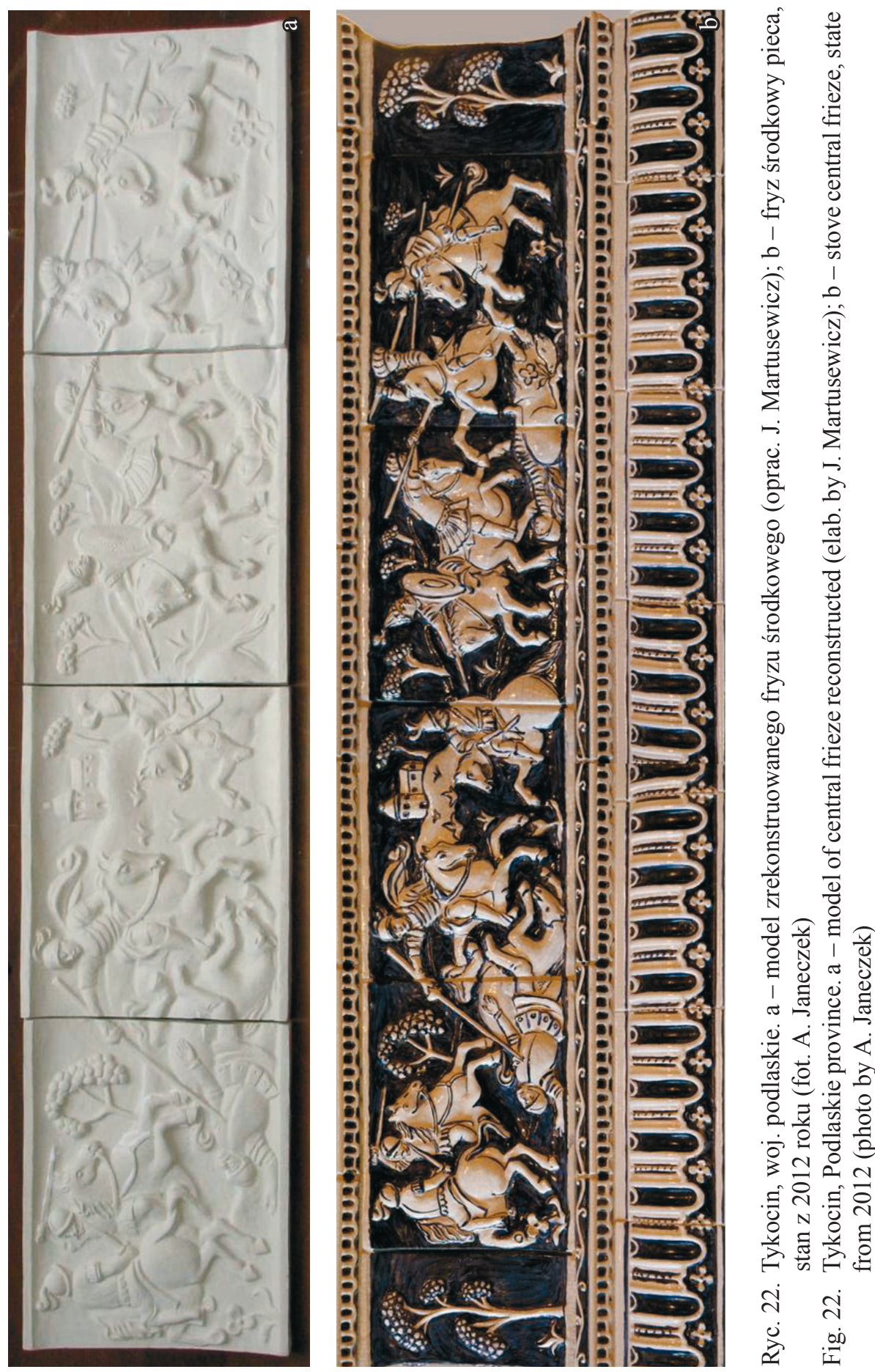
Również poprzez ikonografię pieców bliższy staje się nam świat duchowy ówczesnych odbiorców. Problemy te wymagają dalszych badań, jednak wydaje się, że na postawione w tytule pytanie można odpowiedzieć twierdząco - rzeczywiście poprzez zdobnictwo pieców możemy poznać dawne idee i wzorce do naśladowania. Ale też w głębokiej tradycji pozostaje nadal ognisko otwarte - symbol ciepła i ogniska domowego, przyjaźni i bezpieczeństwa (Ciołek 1976, s. 98).

\section{Literatura}

Borowski A.

2001 Sarmatyzm, [w:] Słownik sarmatyzmu, idee pojęcia symbole, red. A. Borowski, Kraków, s. 175-179.

Chorowska M.

2003 Rezydencje średniowieczne na Ślasku. Zamki, pałace, wieże mieszkalne, Wrocław.

Ciołek T. M., Olędzki J., Zadrożyńska A.

1976 Wyrzeczysko o świętowaniu w Polsce, Białystok.

Dąbrowska M.

1994 Piec z poczatku XVII wieku. Opracowanie projektu rekonstrukcji dla Zamku Królewskiego w Warszawie, Kronika Zamkowa, nr 1/29, 2/30, s. 15-29.

2006 Piecena zamku w Tykocinie, [w:] Czas na Podlaskie. Tykocin. Referaty z sesji historycznej, 3 września 2005, red. B. Pacholska, Białystok, s. 65-75.

2007 O siedemnastowiecznych kaflach i piecach z terenu ziem polskich, [w:] Średniowieczne i nowożytne kafle. Regionalizmy - podobieństwa - różnice, red. M. Dąbrowska, H. Karwowska, Białystok, s. 143-159.

2008 Ogrzewanie wnętrz mieszkalnych $w$ średniowieczu i czasach nowożytnych, Kwartalnik Historii Kultury Materialnej, R. 56, nr 3-4, s. 305-324.

2010 Starość ośmieszona, czyli Filis na Arystotelesie, Kwartalnik Historii Kultury Materialnej, R. 58, nr 1, s. 143-152.

Dymek K.

1995 Średniowieczne i renesansowe kafle ślaskie, Wrocław.

Forstner D.

1990 Świat symboliki chrześcijańskiej, Warszawa.

Gotyckie malarstwo

1984 Gotyckie malarstwo ścienne w Polsce, red. A. Karłowska-Kamzowa, Poznań. Grygiel R.

1987 Średniowieczna siedziba rycerska Zarembów w Jarocinie, Zapiski Jarocińskie, z. 14.

1989 Późnogotyckie kafle piecowe z Jarocina, Zapiski Jarocińskie, z. 17-19.

1993 Późnogotycki piec rycerski z Jarocina, [w:] Cz. Strzyżewski, Kafle gotyckie i renesansowe na ziemiach polskich. Katalog wystawy, Gniezno, s. 35-36. 
2001 Piece kaflowe typu rycerskiego wyrazem programu ideowego rezydencji późnośredniowiecznej i nowożytnej na terenie Wielkopolski, [w:] Rezydencje w średniowieczu i czasach nowożytnych, red. E. Opaliński, T. Wiślicz, Warszawa, s. 219-251.

Gumiński S., Olszewski A. M.

1963 Gotycka wieża mieszkalna w Witkowie i jej renesansowa dekoracja, Biuletyn Historii Sztuki, R. 25, nr 4, s. 312-315.

Holl I.

2003 Der Matthias-Beatrix-Ofen der Budaer Werkstatt (1480-er Jahre), Acta Jakimowicz T.

Archaeologica Academiae Scientiarum Hungaricae, R. 54, s. 255-272.

2001 Sibi et posteritate. Treści ideowe rezydencji feudalnej $w$ Polsce XVI-XIX w., [w:] Rezydencje w średniowieczu i czasach nowożytnych, red. E. Opaliński, T. Wiślicz, Warszawa s. 252-267.

Janiak T.

2003 Kafle gotyckie w zbiorach Muzeum Poczatków Państwa Polskiego w Gnieźnie, Gniezno.

2007 Kafle gotyckie z Wielkopolski, [w:] Średniowieczne i nowożytne kafle. Regionalizmy - podobieństwa - różnice, red. M. Dąbrowska, H. Karwowska, Białystok, s. 17-35.

Kajzer L.

2007 Herby na kaflach z zamku w Ujeździe, czyli o zagadnieniu, ,herbarzy ceramicznych”, Kwartalnik Historii Kultury Materialnej, R. 55, nr 1, s. 21-31.

Karłowska-Kamzowa A.

1965 Gotyckie malarstwo ścienne na Śląsku, Rocznik Sztuki Śląskiej, t. 3, s. 27-93.

1984a Śląsk, [w:] Gotyckie malarstwo, s. 79-107.

1984b Spis obiektów, [w:] Gotyckie malarstwo, s. 193-243.

1991 Sztuka Piastów Śląskich w średniowieczu, Warszawa-Wrocław.

Kębłowski J.

1976 Polska sztuka gotycka, Warszawa.

Kilarska E.

1992 W przededniu odbudowy pieca w Dworze Artusa w Gdańsku, Porta Aurea, R. 1, s. 151-189.

Konecki M., Małkiewiczówna $\mathrm{H}$.

1984 Matopolska, [w:] Gotyckie malarstwo, s. 13-77.

Maroszek J.

2000 Pogranicze Litwy i Korony w planach króla Zygmunta Augusta, Białystok.

Morka M.

1984 Wzorce graficzne polskiego malarstwa batalistycznego w XVII w., Biuletyn Historii Sztuki, R. 46, nr 2-3, s. 210-256.

2006 Sztuka dworu Zygmunta I Starego. Treści polityczne i propagandowe, Warszawa.

Motylewska I.

2008 Renesansowe kafle z zamku w Inowłodzu, Łódź. 
Nadolska K.

1988 Kafle z zamku biskupów włocławskich w Raciążku na Kujawach, Acta Universitatis Lodziensis, Folia Archaeologica, nr 9, s. 85-136.

Nocuń P.

2009 Filis ukonorowana. Głos $w$ dyskusji na temat urządzeń grzewczych $w$ wieży książęcej w Siedlęcinie, Z otchłani wieków, R. 64, nr 1-4, s. 310-314.

Piątkiewicz-Dereniowa M.

1960a Kafle wawelskie okresu wczesnego renesansu, Studia do Dziejów Wawelu, t. 2, s. 303-375.

1960b Rekonstrukcja dawnych wawelskich pieców kaflowych, Biuletyn Historii Sztuki, R. 22, nr 3, s. 331-332.

1982 Renesansowe kafle wawelskie, Warszawa.

Rutkowska-Płachcińska A.

1978a Osadnictwo i zaludnienie, [w:] Historia kultury materialnej Polski, t. 2, red. A. Rutkowska-Płachcińska, Wrocław, s. 11-39.

1978b Budownictwo, [w:] Historia kultury materialnej Polski, t. 2, red. A. Rutkowska-Płachcińska, Wrocław, s. 150-179.

1978c Mieszkanie, higiena, [w:] Historia kultury materialnej Polski, t. 2, red. A. Rutkowska-Płachcińska, Wrocław, s. 312-357.

Sas-Zubrzycki J.

1915 Kaflarstwo polskie, Lublin.

Sawicki T.

1993 Kafle gotyckie i renesansowe z Gniezna, [w:] Cz. Strzyżewski, Kafle gotyckie Strzyżewski Cz. $i$ renesansowe na ziemiach polskich. Katalog wystawy, Gniezno, s. 40-43.

1993 Gotyckie i renesansowe kafle z Jankowa Dolnego, [w:] Cz. Strzyżewski, Kafle gotyckie i renesansowe na ziemiach polskich, Gniezno, s. 37-39.

Szypowscy M. i A.

b.r.w. Serce Gdańska, Warszawa.

Tarasiński A.

2007 Kafle gotyckie i wczesnorenesansowe z terenu Ziemi Bytomskiej, [w:] Średniowieczne i nowożytne kafle. Regionalizmy-podobieństwa-różnice, Witkowski J. red. M. Dąbrowska, H. Karowowska, Białystok, s. 45-49.

1995 Dekoracja heraldyczna wielkiej Sali na zamku w Żarach, Kwartalnik Architektury i Urbanistyki, t. 40, z. 1, s. 69-73.

2002 Szlachetna a wielce żałosna opowieść o panu Lancelocie z Jeziora. Dekoracja Żemigała M. malarska Wielkiej Sali wieży mieszkalnej w Siedlęcinie, Wrocław.

1987 Ogrzewanie piecowe na zamku w Bolesławcu nad Prosna XIV-XVII w., Wrocław. 
A STOVE AS AN IDEA MEDIUM?

Summary

Since the turn of $12^{\text {th }}$ century, gradual civilization transformations, which also had significant impacts on house living conditions were observed in the area of Polish grounds. Fire places and furnaces of hypocaustum type came into use from $13^{\text {th }}$ century, and from $14^{\text {th }}$ century - tile stoves. The last mentioned, except for heating functions, served also as typical element of interior decoration, particularly from the moment of introducing stoves with flat tiles. First designers of this type of stove may have been recruited from builders and architects in later periods. All its construction process involved work of wood-carvers - makers of patrixes and moulds and potters of course - tile makers and stove builders.

Rich gothic tiles ornamentation from the territories of Polish grounds was presented to us thanks to archaeological explorations, among the others, in: Jankowo Dolne, Jarocin, Gniezno. Motifs, as a rule, repeat the same thematic groups; tiles presenting coat of arms, religious elements and symbols, court life scenes, illustrating literary subjects, architectonic motifs, animals and plants. Similar elements can also be found in single and fragmentarily preserved polychrome of that period. Both - stoves and painting may have been a part of common iconographical program for interiors in residences and patriciate houses, which was supposed to be a kind of territorial, group and cultural membership manifestation.

In Renaissance period, ornamentation and subjects of tile images changed. Exceptional objects of that time include, e.g. the stove designed for Wawel castle interior made at order of Sigismund I, placed in the apartments of Queen Elisabeth. In the reconstructed stove we identify portrait tiles of the old and young king, to manufacturing of which images of the kings: Casimir the Jagiellon and John I Albert served as models. Erecting such a stove, additionally decorated in the crown frieze with angles holding shields with the Eagle - the national symbol, and placing it in apartments designed for the Queen, could have been the homage for Queen the Mother from Sigismund's part.

Another example of a Renaissance stove expressing in this case political and religious matters can be a stove erected in Gdańsk Artus Court at the turn of 1545. Placing on tiles portraits of Catholic and Lutheran rulers depicted the situation of not only Gdańsk, but also a huge part of Europe under Habsburg Dynasty reigning.

Next stove presenting by its ornaments current problems of $17^{\text {th }}$ century is the reconstructed stove from Tykocin castle. Tiles obtained during excavations, decorated with family coat of arms of the starost Krzysztof Wiesiołowski and symbols displaying bravery, wealth and Christianity, refer directly to spiritual and intellectual culture of gentry sarmatism of $17^{\text {th }}$ century Polish Republic.

These few stove instants presented herein create the base for rather positive answer to the question placed in the article's title, although they still require further research. 
